\title{
لغة التحية وعبارات المجاملة والتلطف فى الثقافة العربية \\ دراسة سوسيولغوية
}

دكتور: السيد مصطفى محمد عبيد

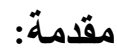

تعد اللغة عنصراً أساسياً في تحديد هويـة أي شعب أو جماعة لغوية، ويشكل الاستخدام اللغوي لهذا الشعب أو

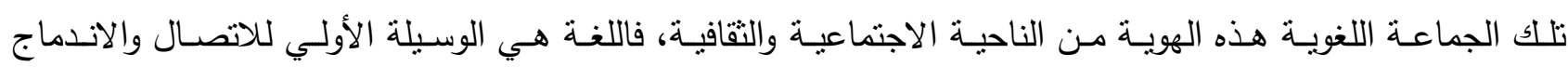
الاجتماعي، والمعبرة عن الفكر والتتوع الثقافي. فاللغة "كائن حي يتفاعل مع كل ظواهر الحياة، يتطور بتطورها ويرقي برقيها، فالجانب الاجتماعي للغنة هو بحق

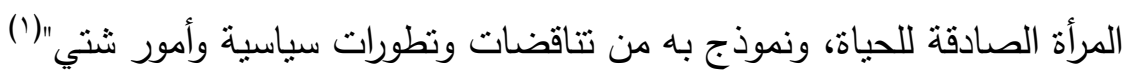
وأول مقتضيات الحياة وبداية أي تواصل لغوي علي المستوي الإنساني هو التحية وعبارات التحية نمط لغوي شائع في كل اللغات واللهجات، ويعبر عن الطوائف الاجتماعية والمهنية والطبقية في لغة من اللغات، كما يؤدي وظيفة مهمة من وظائف اللغة وهي الوظيفة التي تضمن المحافظة علي العلاقات الاجتماعية العادية. ولما كانت " أولي الوظائف اللغويـة أول مظاهر السلوك اللغوي.. هي استعمال اللغـة للتحيـة بأنواعها، ولإظهار التأدب و التلطف، وذلك في المناسبات الاجتماعية المختلفة". (r) فإن "كفاية الإنسان للحياة تعني القدرة علي أن يتكلم ويكتب ويسمع ويقرأ بطريقة نزيد فرصسه وفرص الناس جميعاً

من ثم جاءت فكرة هذا البحث الذي يدرس لغة التحية في التقافة العربية من خلال رصد عبارتها ومقتضايها كما يقوم تحليل هذه التعبيرات من الناحية اللغوية والدلالة الاجتماعية والثقافية، كما يستتبط مرجعيات هذه اللغة ومصادرها المختلفة. وعلاقتها بالمناسبات العامة والخاصة التي قيلت فيها. وما يصاحبها من علامات سيميولوجية أو لغة أثنارية. كما يتتاول البحث الاستخدام الفعلي للغة التحية في المواقف الحياتية المختلفة من خلال رصدها في نموذج من الرواية العربية، للتعرف علي العوامل والقواعد التي تحكم في هذا الاستخدام بوجه عام بالنسبة للمجتمعات الإنسانية، بدءاً من المناداة وألفاظ التأدب والاحترام والتقدير مروراً بالمناسبات والأعياد وغيرها. ومن ثم يتبين خصوصية لغة التحية في التعبير عن أنماط التقافة العربية والإسلامية في إثراء لغة وغئة التحية وعبارات المجاملة، كما تبرز مصادر تلك اللغة عن ارتباطات منتوعة لهذه اللغة الخاصة التي يرجع بعضها إلي الموروث اللغوي،

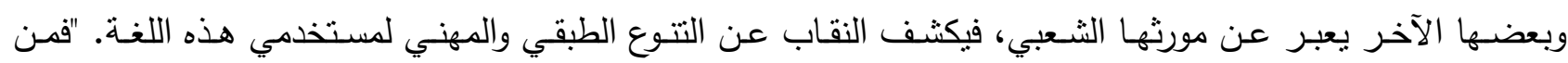
الظواهر الاجتماعية المرتبطة باللغة، أن اللغة وسيلة من وسائل التتصنيف الاجتماعي إلي طوائف أو مهن أو طبقات.

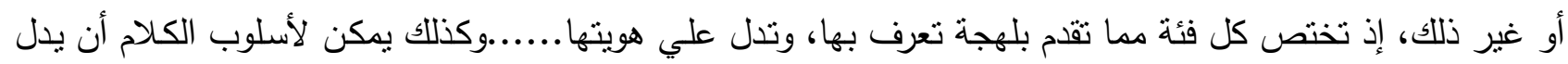
علي المستوي الاجتماعي الذي يختلف أصحاب اللهجة الواحدة بنسبة (). 
مستويات الاستخدام اللغوي للغة التحية:( المجالات الدلالية لألفاظ وتعبيرات لغة التحية ):

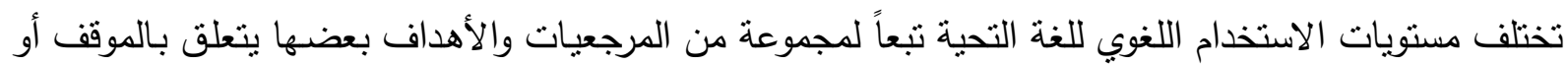

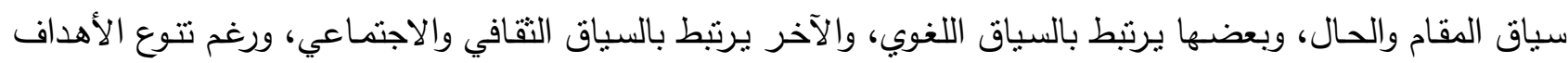
تتتوع سبل ومجالات التحية إلا أنها تشترك في هدف مركزي وهو التواصل الجيد باستخدام أفضل السبل لتحقيق الانسجام في العلاقات، وتيسير المعاملات مع مراعاة قواعد اللياقة التي يجب أن تسود العلاقات والمعاملات الإنسانية.

\section{وقسمت هذه المجالات إلي أربعة مجالات دلالية هي:

$$
\text { النداع- التحية - التلطف - المجاملة }
$$

النداء $\}$

يضم هذا المجال فعلين أساسيين هما : نادي - ينادي - نداء - ومناداة ودعا ، يدعو دعواً ودعاء.

$$
\text { ومن المعني اللغوي: للنداء: }
$$

" النّّداء وإلتُّداء: الصوت مثل الدعاء... وقد ناداه ونادي بـه وناداة منادة ونداء، أبي صـاح بـه، وأندي الرجل إذا

حسن صوته.(๕) والنداء، ممدود: أي الدعاء بأرفع الصوت، وقد ناديته نداءً.

وفي اصطلاح النحو: المنادي: يراد به: المطلوب إقباله بحرف ناب مناب أدعو لفظاً أو تقديراً.(0)

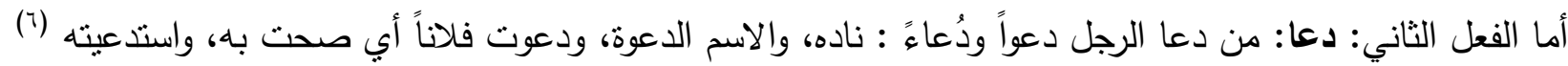

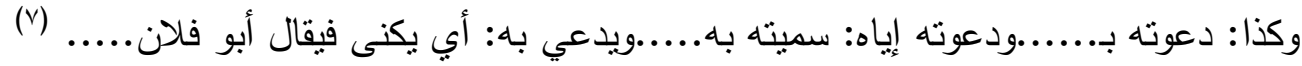

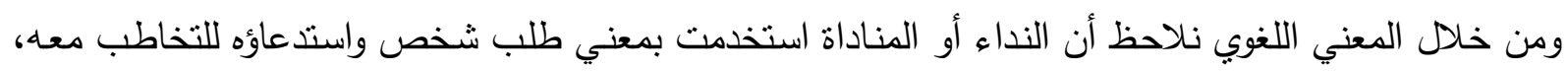
وكذلك دعاه بمعني ناداه، ودعوته بفلان أي سميته بهذا الاسم، ولا يبعد المعني اللغوي عن المعني الاصطلاحي الذي

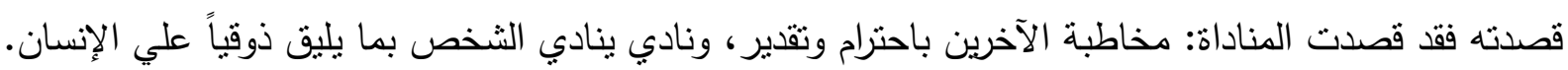
وقصدت من دعا دعوة بأن ينادي الثخص ويدعوه بما يناسبه من أسماء أو كنى، أو باستخدام ألفاظ تدل علي الئي الاحترام والتقدير ومراعاة مكانة الثخص المنادي أو المدعو وسنة ومنزلته من المنُادِي.

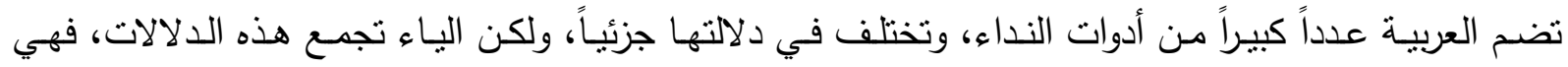
تستخدم للقريب والبعيد. وهي أكثر أدوات النداء دوراناً علي الألسنة. كما ينادي بها المفرد والجمع، ولكن استخدامها في هي دهن المناداة يرتبط بالسياق التي تنتخدم فيه، ومن ثم تتحدد دلالتها. وقد تختلف السياقات من السياق اللغوي والسياق التقافي،

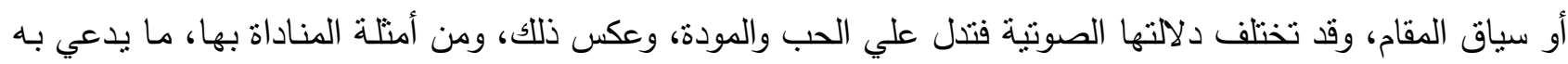

" با رب يا معين. يارزاق، ياكريم. حسن الختام، كل شيء بأمره. مساء الخير يا جماعة" (^)

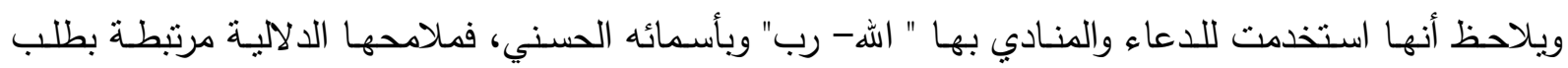
العون، والرزق والكرم، وحسن الخاتمـة من الله والنداء من العبد الضعيف الذي يحتاج من الله بكل ما تتجلي بها صفاته وأسمائه الحسني.

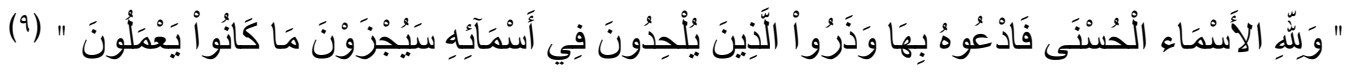

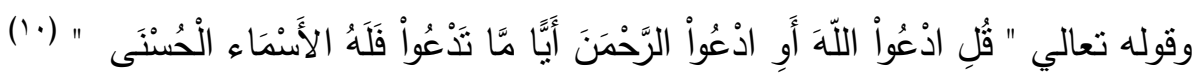
ويأتي نداء ودعاء الرسول في العربية يحمل طابعاً خاصـاً من درجة الصوت وطريقة النداء وألفاظه، يقول تعالي

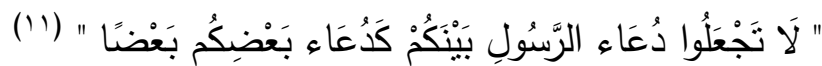


يقول ابن كثير، قال الضحاك عن ابن عباس: كانوا يقولون يا محمد، يا أبا القاسم فنهاهم الله عز وجل عن ذلك إعظاماً لنبيه- صلي الله عليه وسلم - قال: فقولوا: يا نبي اله، يا رسول الله. وهكذا قال مجاهد، وسعيد بن جبير وقال قتادة: أمر الله أن يهاب نبيه- صلي الله عليه وسلم- وأن يبجل ويعظم وأن يسود. (r') فتعظيم اله الرسول بندائه ودعائه بلقب ورسالته أكرم وأعظم أدباً وتفضلاً.

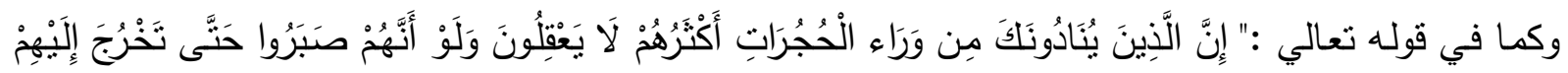

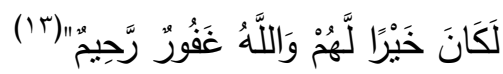

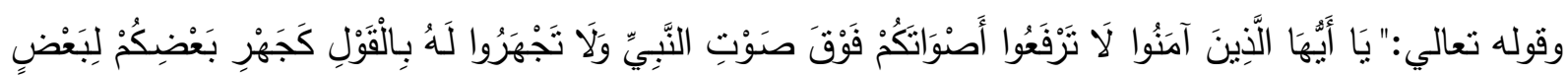

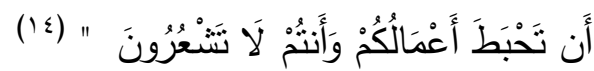
فثرط الله تعالي في الآيات طريقة المناداة، وجعلها خاصـة برسول الله ولا تتساوي مع ندائهم للآخرين سواء أكان ذلك في وقت النداء، أو درجة الصوت، والطريقة التي يؤدي بها.

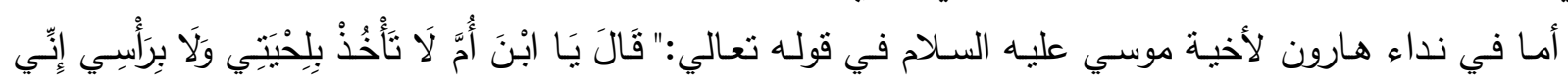

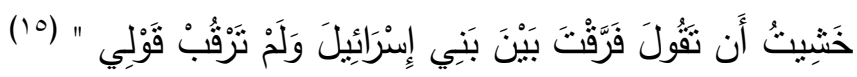
فقد ناداه بقوله: "يا ابن أم" وقد "ترفق له بذكر الأم مع أنه شقيقه لأبوية لأن ذكر الأم ها هنا أرق وأبلغ في الحنو والعطف ولهذا قال يا ابن أم لا تأخذ بلحيتي ولا برأسي ، هذا اعتذار من هارون عند موسي في سبب تأخره عنه حيث لم لم

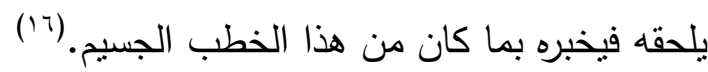
وقد راعي رسول الله هذا اللطف والحنو أيضاً في ندائه علي صغار المسلمين، مستخدماً النداء بالياء مع صيغة التصغير في الاسم المنادي بالكنية في حديثه" - صلي الله عليه وسلم-"يا أبا عمير ماذا فعل النغير" (أي يا أبا عمير

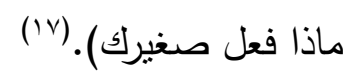
وإذا انتقنا إلي مستوي آخر من مستويات النداء في رواية زقاق المدق لنجيب محفوظ: حيث تدور الأحداث في الزقاق بما يضم من عامة الناس بكل طوائفهم. ينادي عم كامل - بائع البسبوسة بقوله" اصح يا عم كامل وأغلق الدكان".

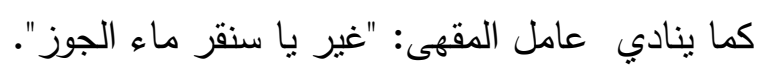

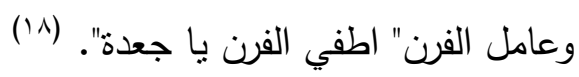
نلاحظ استخدام أداة النداء "يـا" ولكن الطبقة الاجتماعية والعمل أو المهنة تتضـح مـن السياق وكذلك الملامـح الدلالية لكل أسلوب من الأساليب السابقة، فعندما ينادي "بائع البسبوسة وهو رجل أكبر سناً من المنادي : فناداه بلفظ من

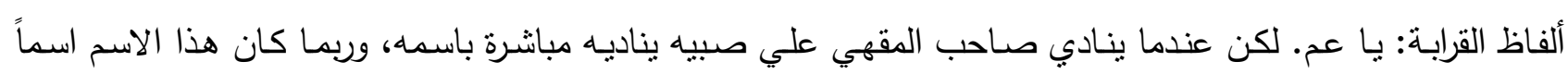

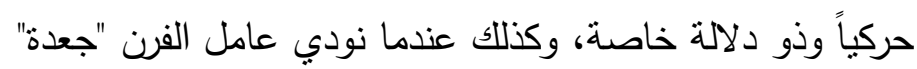
وفي سياق آخر يحمل النداء صيغة الزجر والعنف، ويتضح ذلك من النص التالي من رواية زقاق المدق، والذي يخاطب فيه الشيخ صبي القهوة: "ولما طال انتظاره، ولمس تجاهل الغلام لله، خرج عن صمته قائلاً بصوت غليظ: القهوة يا سنقر .....! ولكن جاءت النجدة من السماء إذا دخل في تلك اللحظة رجل وقد سمع هتاف العجوز ، ولاحظ إهمال الصبي، فقال للغلام بلهجة الأمر :- هات قهوة الثاعر يا ولد.. 
وحدج الثاعر القادم بنظرة امتتان، وقال بلهجة لم تخل من أسى:

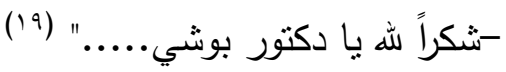

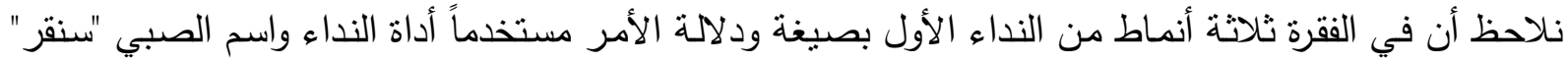

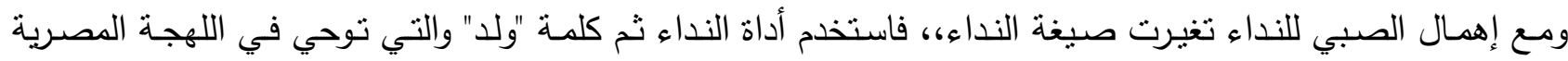
بتحقير من ينادي بها أو تقليل من شأنه أو مكانته أو سنه.

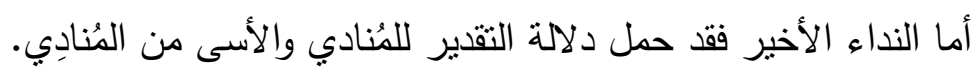

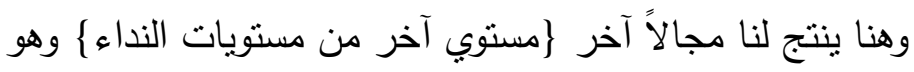

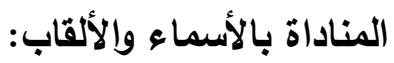

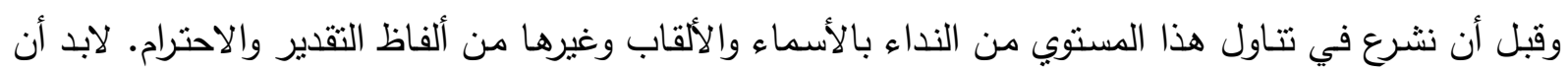

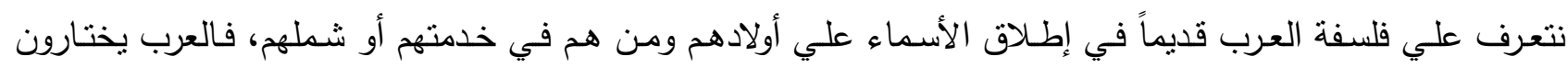

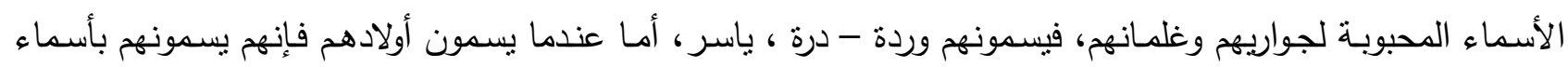
فيها الجفوة والقوة لذا يقولون: أننا نسمي جوارينا لنا ونسمي ونهي أبناءنا لأعدائنا.

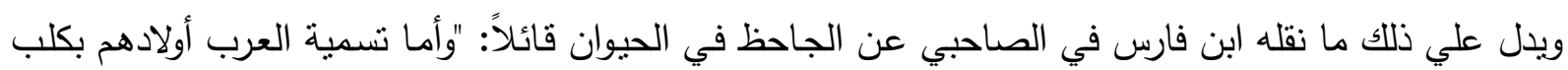

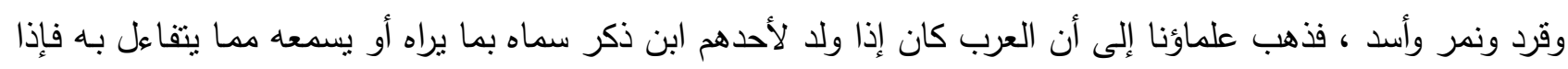

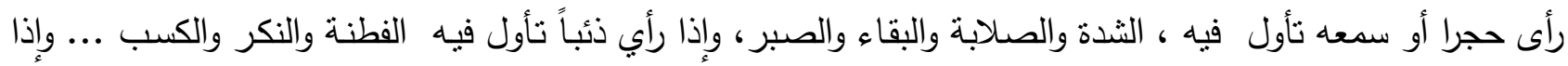

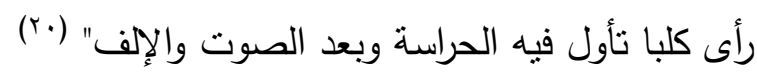

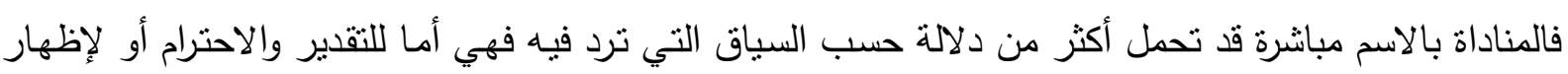

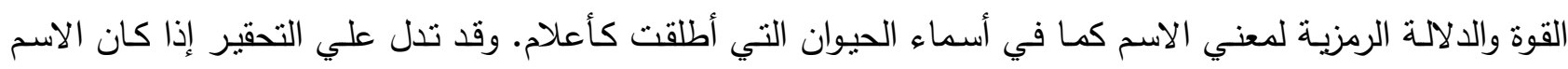
يحمل هذه الدلالة. وأحياناً يستخدم العرب بعض الصيخ الصرفية للاسم لإضفاء دلالة خاصة عليه، كإدخال "أل" التعريف علي الاسم العاء

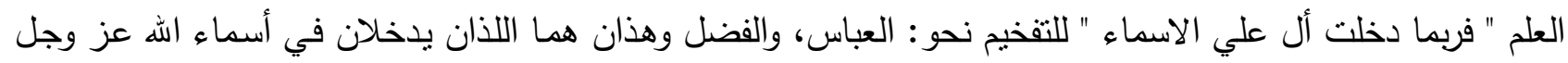

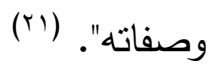
أما الألقاب التي يتنادي بها العرب " فعلي ثلاثة أضرب: ضرب للمدح ، وضرب للذم وضرب نلقيب الإنسان

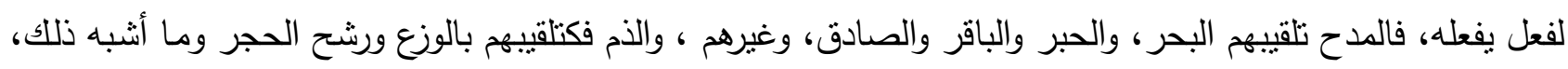

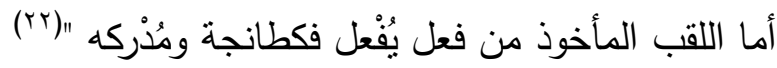

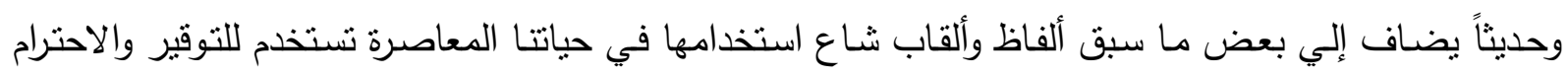

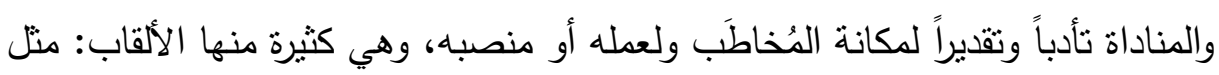

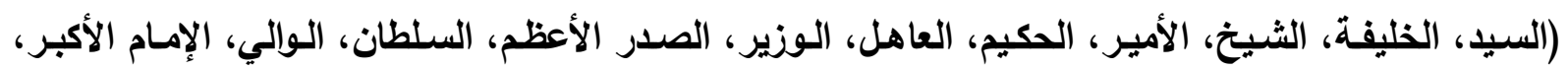

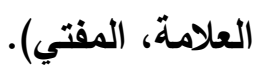
ومنها ما هو للتقاير ويسبق الاسم متلك: فخامة- معالي - نيافة- قداسة مونة وتجمع كلمات هذا الدجال الدلالي: دلالة التقدير والاحترام والتقدم والعلو، ولكن تبقي الدلالة الخاصة والمنفردة لكل

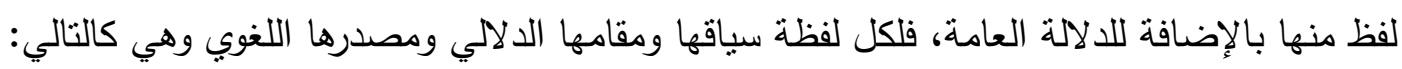


السيد: لغةً من ساد، سيادة وسودداً وسؤوداً :شرف ومجد ،وساد قومه: صار سيدهم ومنسلطاً عليهم. والسيادة كرم المنصب، والقدر الرفيع. أما اصطلاحاً وتحية مناداة:

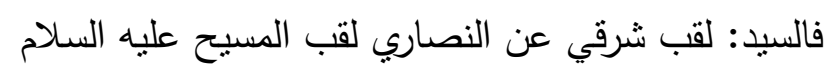
وعند المسلمين: بطلق علي من كان من السلالة النبوية، والسيدان : هما الحسن والحسين و علي بن أبي طالب.

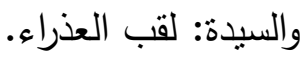

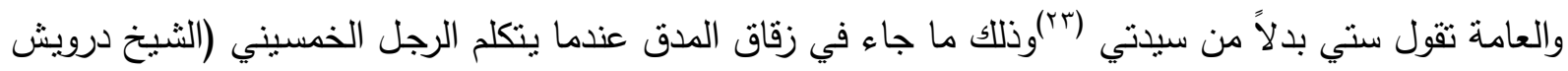

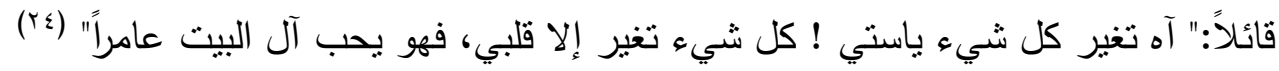

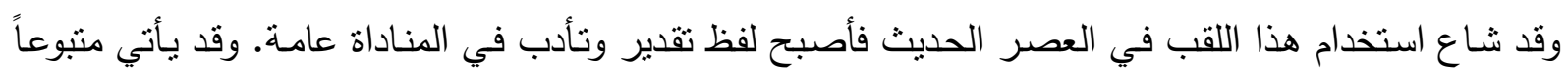
باسم العلم المنادي وقد يأني منسوباً دون العلم.

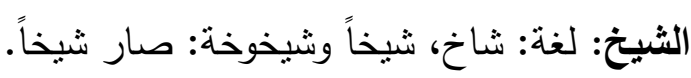
اصلاحاً للمناداة: إذا نودي به، وقال له يا شيخ: فهو للتبجيل.وقد يكون للتودد فى بعض السياقات،

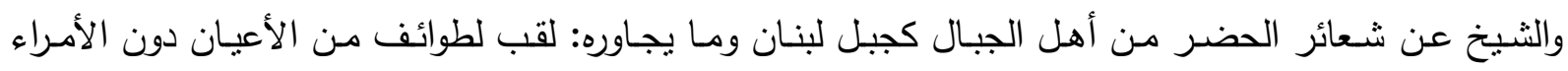
والمقدمين. ويطلق الثيخ علي الأستاذ والعالم وكبير القوم ورئيس الصناعة ،وعلي كل من كان كبيراً في أعبان القوم علماً أو فضلاًا أو مقاماً. (ro) وقد أطلق اللقب علي كبار العلماء من الأزهر الثريف، وأصبح منصباً إدارياً وهو " شيخ الأزهر" "والثيخ الأكبر:

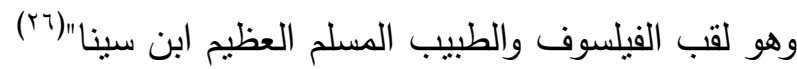

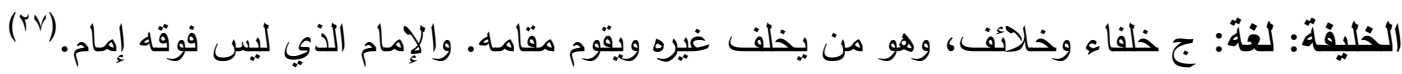

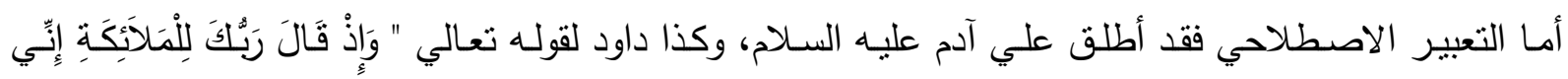

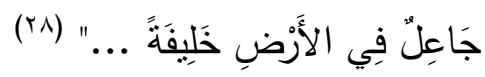

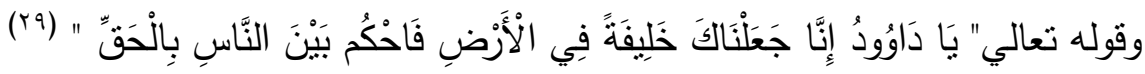

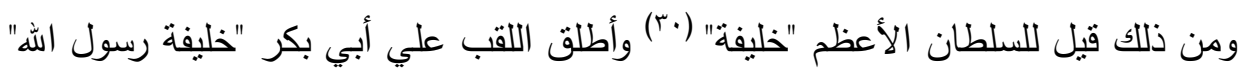

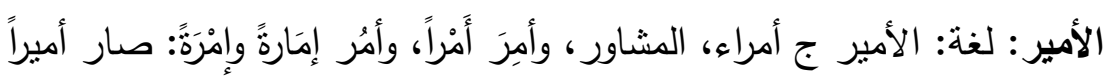

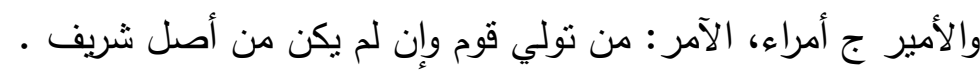

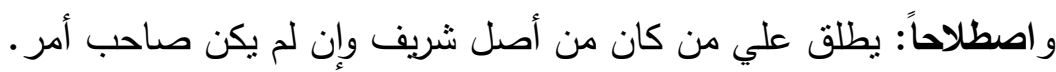

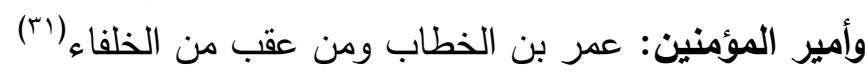

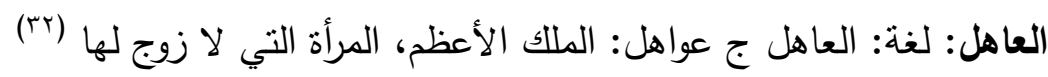
اصطلاحاً: العاهل اصطلاح " قديم ومعاصر يقصد بـه الملك مثل العاهل الأردني، والعاهل المغربي،، وفي العربية العادية

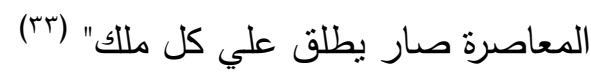

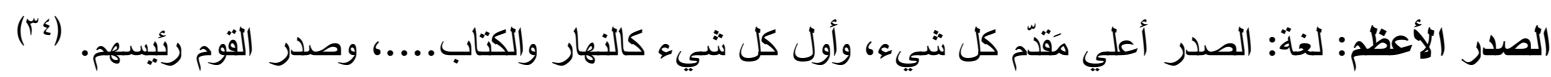
في مصطلح الألقاب والمناداة: - الأن: 
الصدر الأعظم: الوزير الأكبر" وهو تعبير معاصر للالالة علي الوزير الأكبر في الدولة العثمانية، وهو منصب يعادل

رئيس الوزراء في عصرنا" (ro)

السلطان: لغة: سَلَّطة وستلط عليه: غلبَّة وأطلق له وعليه القدرة والقهر والسُّلْة: الملك، والقدرة.

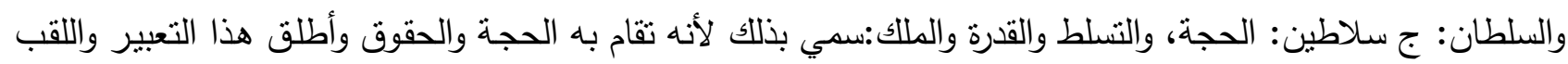
حديثاً علي السلطان قابوس سلطان بن عُمان: وفي التعبير الاصطلاح هي : سلطان العاشقين : هو لقب أطلق علي الشاعر الصوفي الكبير :عمر بن الفارض • وسلطان العلماء: تعبير قديم: وهو لقب شيخ الإسـام العز بن عبد السـلام.

الوالي: لغة: وَالي: ولاء وموالاة الرجل: صادقة وناصرة، وأولَّي: إيلاء فلان الأمر : صار والياً عليه. والوالي: (ج) ولاة وإلي البلد المتسلط عليه وحاكمه. وفي التعبير : "اله وليك" أي حافظلك وساهر عليك. " والمؤمن ولي الله " أي مطيع لله تعالي. وعند المسلمين. كالقديس عند النصارى. وفي التعبير المعاصر : "ولي العهد" : وريث الملك ، "ولي اليتيم": الذي يلي أمره ويقوم بكفايتة. (rv)

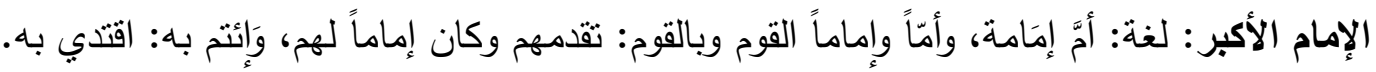

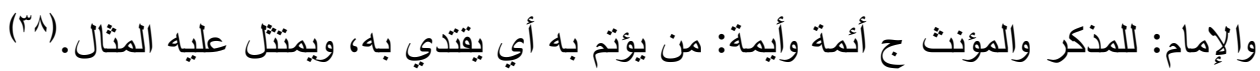
الإمـام الأكبر : لقب بطلق علي شيخ الجامع الأزهر بمصر، وقد تم منح هذا اللقب بصدور القانون رقم بــــ لسنة

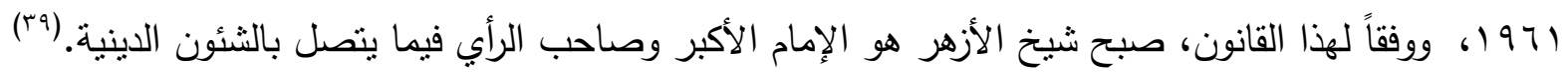

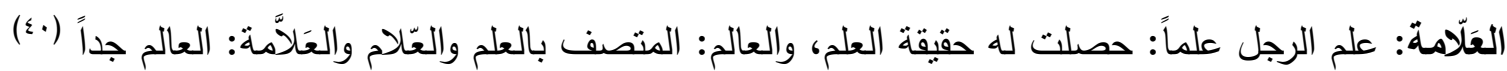
اصطلاحاً: والعلامة علي وزن فعالة هو لقب غالباً ما يستعمل في أوساط علماء المسلمين ويطلق علي الثخص كثير

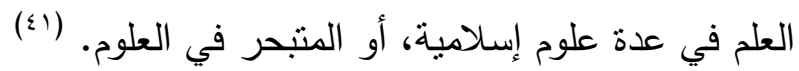

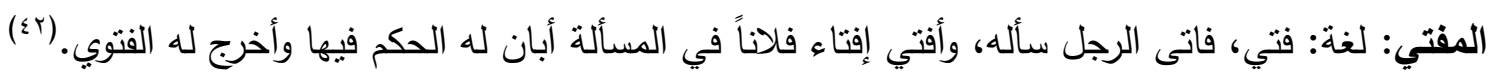
و اصطلاحاً هو لقب يطلق علي العالم المسلم الفقيه المصرح له بالفتوى في أمور الدين وهو العالم بالمسألة التي يفتي فيها، تأسيساً لا تقليداً. أما ألفاظ وألقاب التقدير والتحية (فخامة- معالي - ونيافة- وقداسة) فلكل لفظ منها دلالة عامـة للإكبار والتقدير ولكن لكل لفظ أيضاً ملمحاً دلالياً يستقل به عن الألفاظ الآخري.

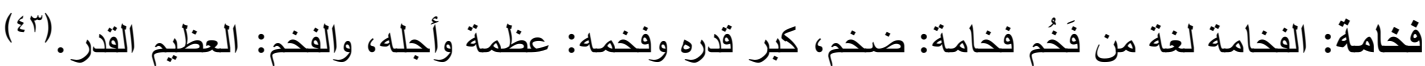
وإصطلاحاً: يطلق علي الرئيس "فيقال: فخامة الرئيس: وهو صفة فخرية خاصة برؤساء الدول تعظيماً لمكانتهم، ومنها "صاحب الفخامة". نيافة: لغة: ناف ينوف الثيء: ارتفع، وينف تتييفاً علي كذا: زاد والنَيِّف: الفضل والإحسان، وإمرأة منيفة: تامة

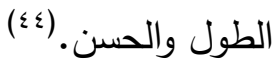
ونيافة: لقب الكردينال في الكنيسة الكاثوليكية. من خـلال استعراض ألفاظ هذا المجال الدلالي الأول (المناداة) لوحظ أن ألفاظ المجال يضمها معني عام هو الإكبار والتقدم وعلو المكانة أو الثـأن كما تتوعت مصـادر ومرجعيات ألفاظ هذا المجال، الذي غلب المرجع الإسـلامي علي كثير من ألفاظه مثل السيد، والإمام، والمفتي. ومنها ما يرجع إلي الديانة المسيحية مثل السيد المسيح، وكلمة نيافة 
للكنيسة الكاثولوكية. بينما يعد المرجع الثقافي المرتبط بالبيئة والمجتمع حيث برجع كلمة "ثيخ" لجبال لبنان، وكلماتعاهل و أمبر و والي وفخامة إلي مرجعيات سياسية وإدارية. هناك عبارات وألفاظ اتسعت دلالتها مثل كلمة (سيد - السيد) فأصبحت لفظة تقدير عام وتقديم بلياقة، وكذلك لقب وتبات (شيخ) و بيه ،حاج، وانحسرت دلالات كلمات منها (أتابك - خديوي سلطان، والي) فقل شيوعها واستخدامها في الحياة المعاصرة كلقب أو لفظة مناداة. وفي المقابل زاعت وانتشـرت كلمات مثل (حضرثلك - سيادة - معالي) في الاستخدام الدبلوماسي والإداري في الحياة اليومية لدي العرب.

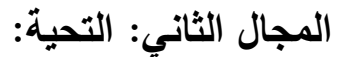
لغةًً: حيا :الحياة نقيض الموت. حَيََ حياةً وحَيّ تحَيًَا فهو حَيُّ. وللجميع حَيّوا. والتحية تفعلة من الحياة.

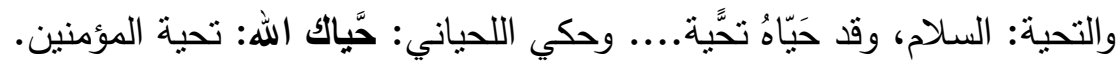

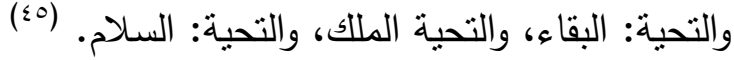
اصطلاحاً: قصدت استخدام التحية في هذا البحث بمعني إلقاء السلام. والدعاء بها، والبقاء سالماً سعيداً. فالتحية في كلام العرب ما يحيب به بعضهم بعضاً إذا تلاقوا. فالتحيات تحية "هي أن ثقول: "حباك الهه" أبي جعل للك الحياة، وذلك إخبار، ثم جعل دعاء، ويقال حبا فلان فلاناً

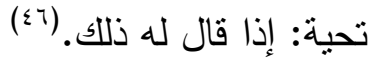
وتختلف التحية أسلوباً وطريقة وألفاظاً و تعبيرات من مجنمع لآخر ومن لغة لآخري ومن ثقافة لنقافة، فقد كانت

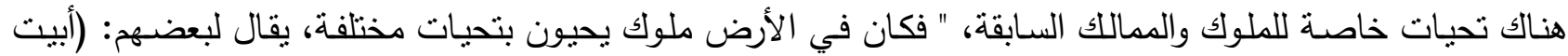

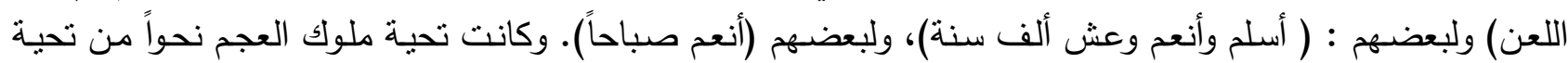

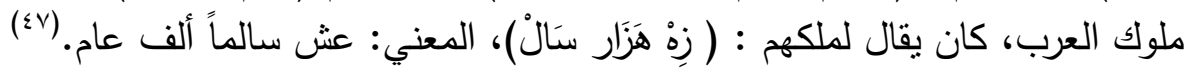
وعندما نزل القرآن وفرضت الصلاة جعلت للمسلمين تحية خاصة في حياتهم اليومية، وتحية خاصة في في صلاتهم.

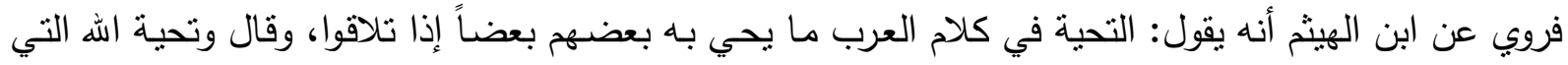

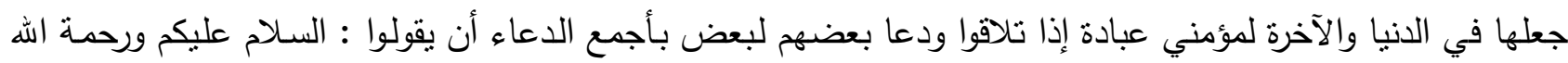
وبركاته. (ఓ^)

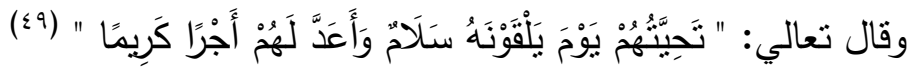

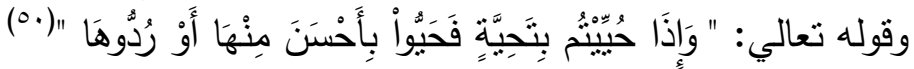
أما تحية الصلاة (التحيات لهاله) "إنما جعلت التحيات، لأن كل واحد من ملوكهم كانت له تحية يُحيَّا بها، فقيل لنا "التحيات لله"...وقال أبو بكر

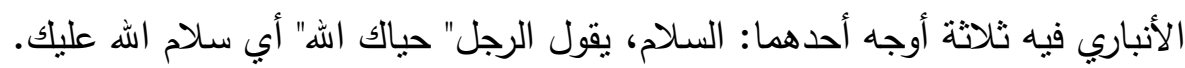

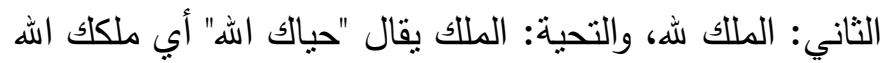

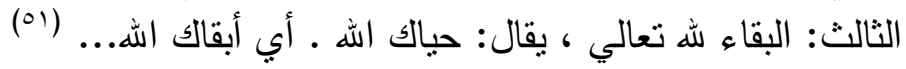

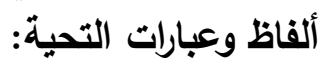
تدور ألفاظ وعبارات هذا المجال حول محور أفعال ثلاثة رئيسية هي : ا-حيا (تحية) ومنها اشتقت الحياة والدعاء بدواتهات هوان ץ-سلم يسلم سلام، فإذا كان التحية من الحياة، فالسلام والسلامة فيها هي عمادها والصحة تاجها.

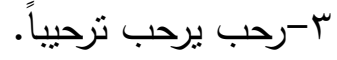

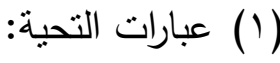

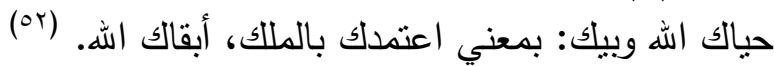

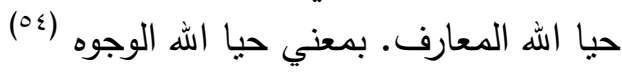


وقيل : هو من استقبال المحيا، وهو الوجه، وقيل فَرحك وسلم عيلك، وهو من التحية والسلام. (00)

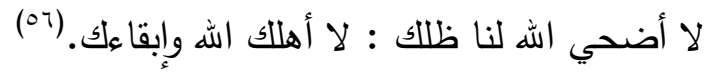

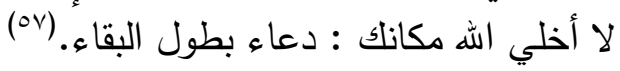

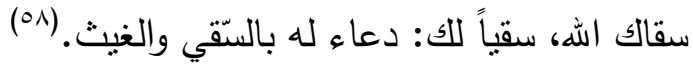

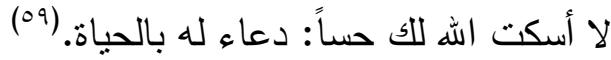
صبحكم الله بالخير : تحية ودعاء جاءكم بالخير صباء لهاء هذه الليلة. 
(السلام، والسلام عليكم ، والسلام عليكم ورحمة الله وبركاته)

كلها عبارات تحيـة الإسـلام التي اختارها اله لعباده المؤمنين، ولرسـه المكرمين، وملائكته المقربين، وهي أكثر عبارات التحية شيوعاً، لأنها صالحة في كل وقت. يقول تعالي:

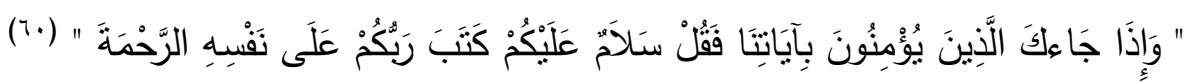

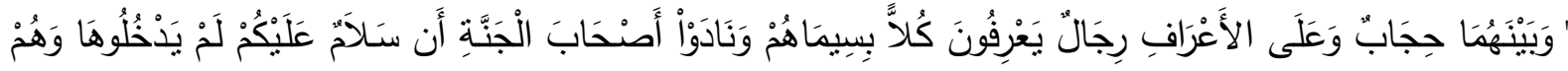

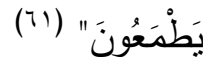

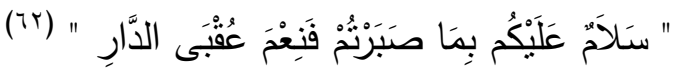

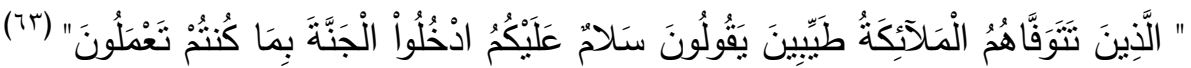

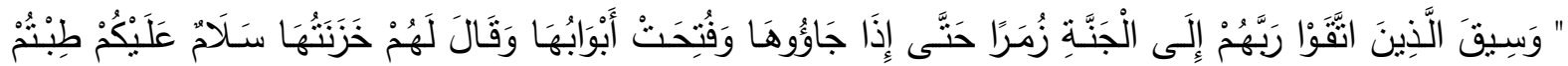

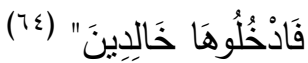
وقد وردت عبارة (السلام عليكم) كتحية في القرآن الكريم سبع مرات.

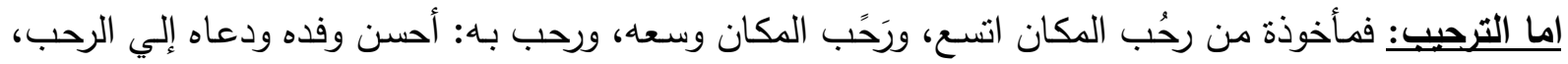

$$
\begin{aligned}
& \text { وقال له مرحباً، والترحاب: الدعاء إلي الرَحب (70) } \\
& \text { أثنهر عبارات الترحيب: } \\
& \text { مرحبـاً بك : أي صادفت سعة ورحباً. } \\
& \text { أهـلاً ومرحباً : أي أتيت أهلاً وأتيت سعة. } \\
& \text { أهلاً وسهلاً : أي أتيت أهلاً ونزلت سهلاً. }
\end{aligned}
$$

تلك العبارات المباشرة التي ثقال تحية للوارد ، وهناك عبارات غير مباشرة تكون لدعاء للقادم وإكراماً له مثل: نعم

الله بك عيناً: بمعني أقربك عين من تحب القبارت وأيضا : انت على عيني: أنت في حفظي ورعايتي - إكرامي

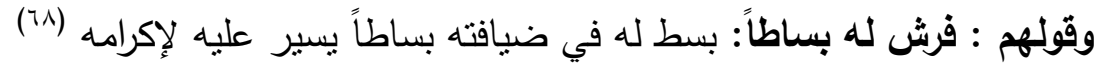
كما تدور على ألسنة العامة من الناس عبارات أخري مثل سررت بلقائك، أنا مسرور بلقاءك، مما يدخل في مجال المجاملة، في المواقف الحياتية المختلفة، كما سيأتي: المجال الثالث (المجاملة) : المبل

كلمـة مجاملة - فعلها الأصلي - جمُل ، ومزيده جامل يجامل مجاملة، وللمجاملة معانَ يقول الفراء: المجامل الذي يقدر على جوابك، فيتركه إبقاءً على مودتلك، والمجامل الذي لا يقدر على جوابك فيتركه، ويحقد عليك إلي وقت ما.

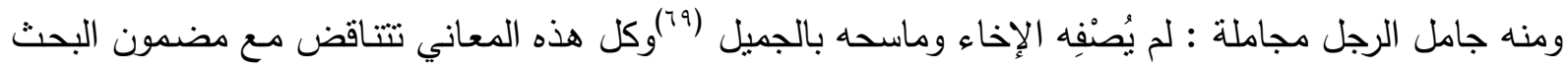
وموضوعه وهدفه، وإنما قصدت بالمجاملة من تجميل القول والفعل والخلق، كما يقول ابن سيده: (الجمال الحسن يكون

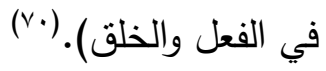


ومن ثم فالمصطلح المقصود بالمجاملة في هذا البحث هو : المعاملة بالجميل

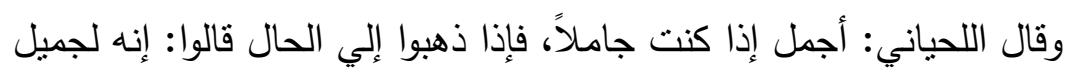

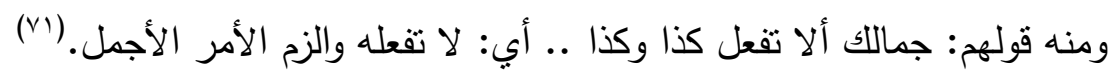

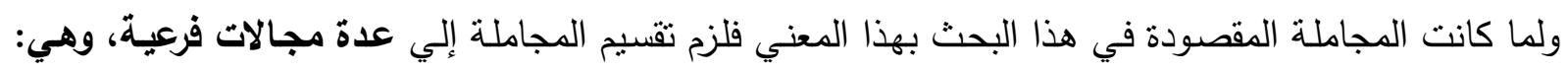

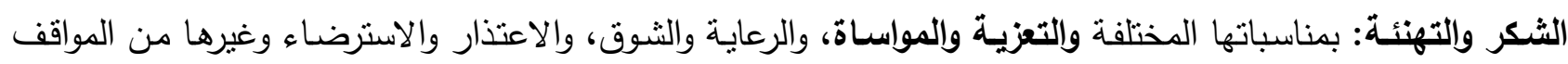
الحياتية التي تستخدم فيها التعبيرات الثابتة والاصطلاحية كنوع من الدعاء أو إظهار المودة. (1) الثكر والحمد: (1) الثنات

$$
\text { ويضم هذا المجال الفرعي كلمات: (الثكر - الثناء - الجزاء - الامتنان - المدح) }
$$

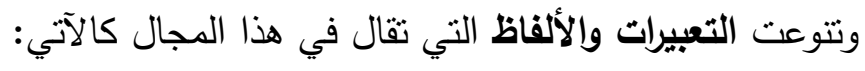

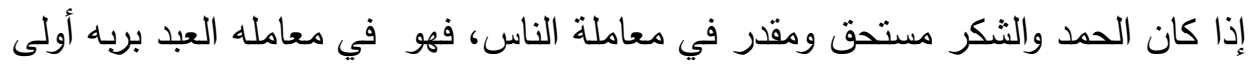

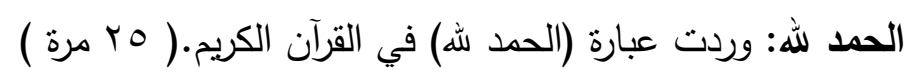

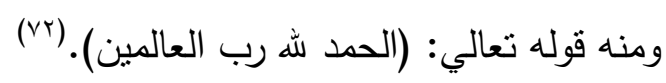

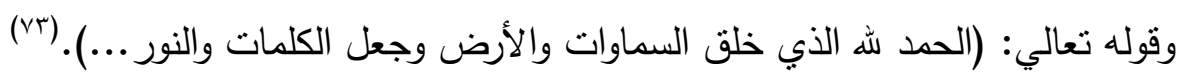

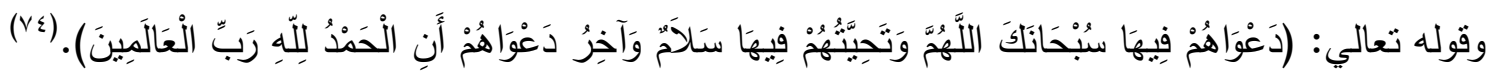

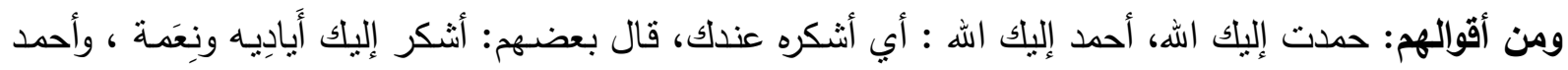
معك الله.

$$
\text { وقول العرب في المثل: العود أحمد - أبي أكثر حمداً. }
$$

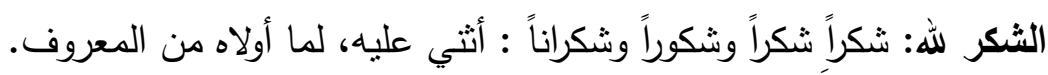

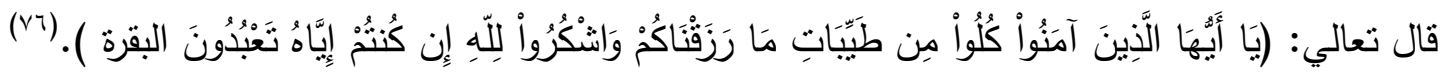

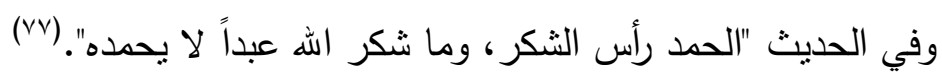
وقول العرب "ثكر الله سعيك" أي أثنابك.

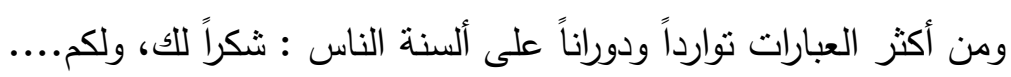
ومنها شكرت فلانا ، وشكرت لفلان نعمته أو فضله.

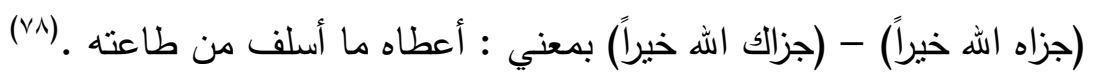
ومن خلال تحليل ألفاظ وتعبيرات هذا المجال، نلاحظ وجود علاقات دلالية مثل شبه الترادف بين: الحمد والثثاء

يقول ابن منظور نقلاً عن الازهري: الثكر لا يكون إلا ثناءً ليد أوليتها.

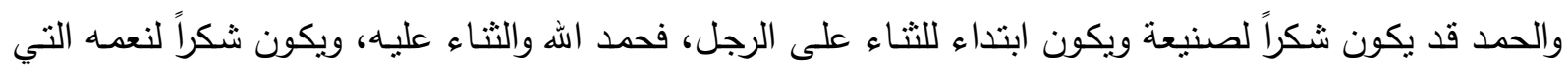
شملت الكل، والحمد أعم من الثكر . (va) ومن ثم فالرابط بين الحمد والثنكر هي علاقة الخاص باصن بالعام.

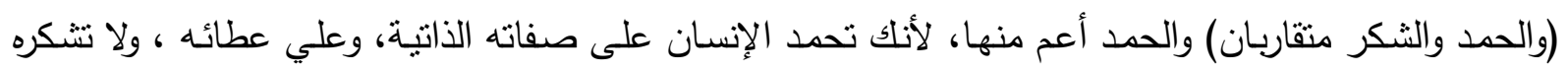

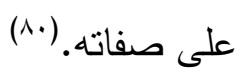
فالعلاقة بينهما شبه الترادف، وليس الترادف التام لوجود بعض الفوارق. 
التهئئة خلاف التعزية، فيقال هنأة بالأمر والولاية، وهنأه تهنئة وتهنيئاً: إذا قلت له: ليهنئك .... والعرب تقول ليهنك الفارس.(1)

ومن ثم فالتهنئة تكون في الأمور والمناسبات المبهجة والأعمال الكبيرة، وهي متعددة كالولاية والزواج والحج

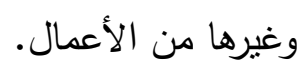

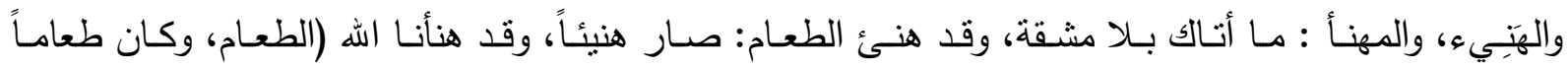

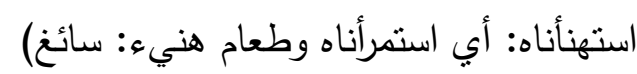

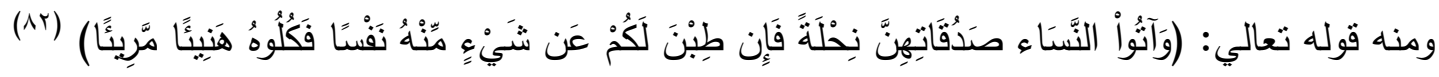

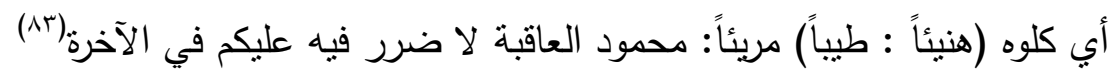

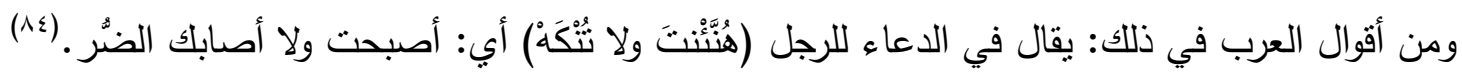

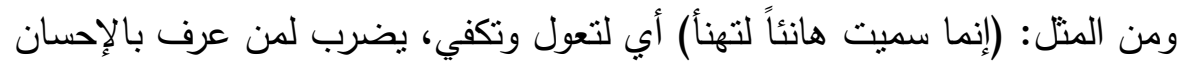
- مناسبات ومواقف التهنئة: - التهنئة بالقرآن والعلم: ومنه تهنئة الرسول (صلي الله عليه وسلم) - بنزول آي القرآن فقد (أخرج الثيخان عن الثنان

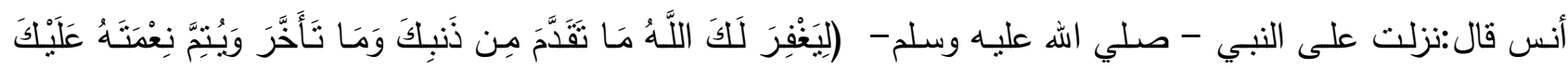

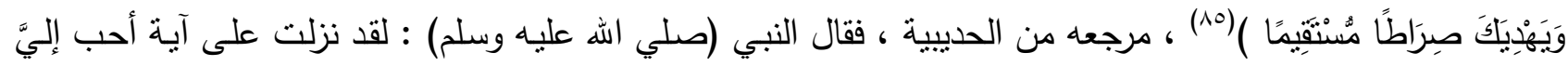

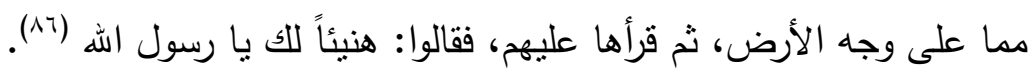

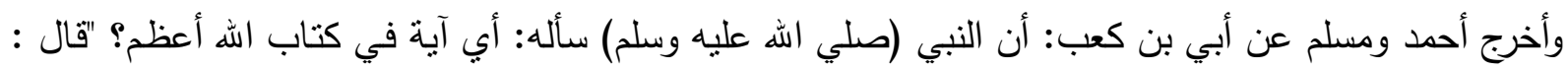

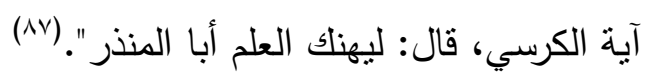

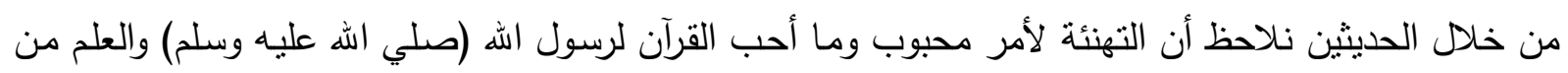

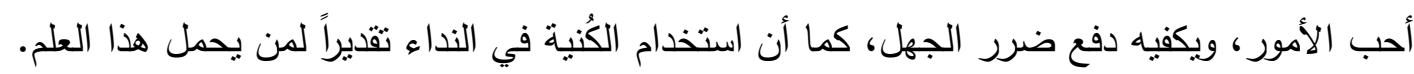
وكذلك التهنئة بالتوبة:

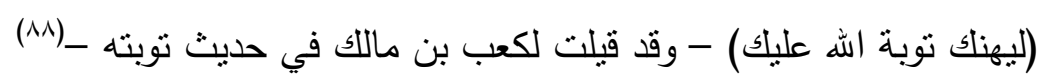

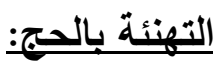

في التهنئة بالحج أقوال بعضها ورد في أحاديث المصطفي (صلي الهه عليه وسلم) مثل ما جاء فيماً روي عن ابن

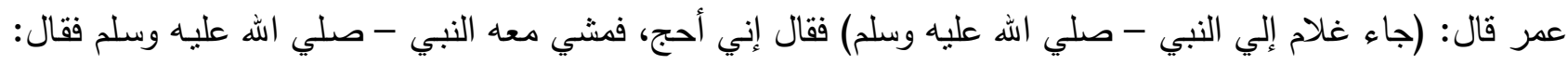
يا غلام، زودك اله الثقوي، ووجهاء الخي الخير ،وكفاك الهم. فلمـا رجع الغـلام سلم على النبي (صلي الله عليه وسلم) فقال: (يا غـلام قبل الله حجك، وغفر ذنبك، واخلف نفقن)

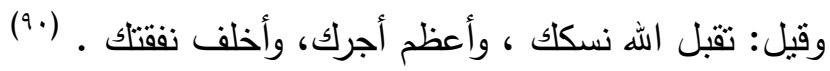
وتقول العامة: حجج مبرور وذنب مغفور. 


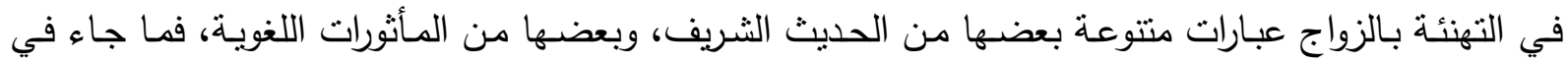

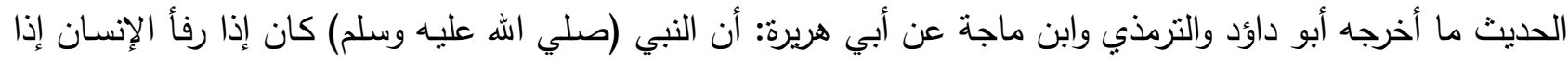

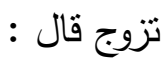

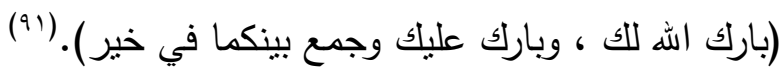

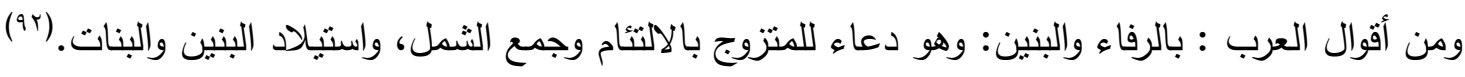

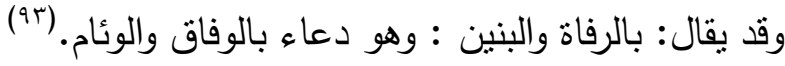

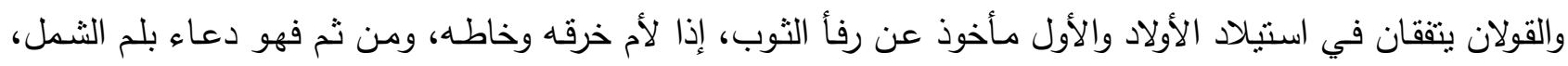

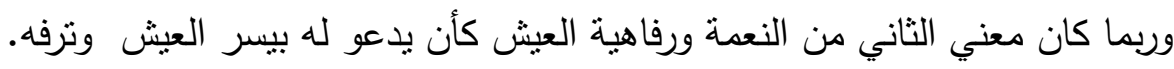
التهنئة بالمولود: اشتهر عند العرب: (قول ليهنك الفارس) تهنئة بالمولود. وهناك خبر (أخرجه الطبراني في الدعاء من طريق السري بن بحيي قال: ولد لرجل ولد فهنأة رجل فقال: ليهنك الفارس، فقال الحسن البصري: وما يدريك؟

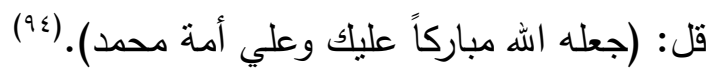
التهنئة بالثوب الجديد:

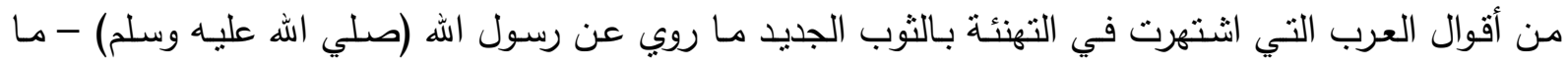
أخرجه البخاري عن أم خالد بنت خالد أن النبي (صلي الله عليه وسلم) كساها قميصه فألبسها بيده، وقال : أبلي وأخلقي مرتين.

وقوله في حديث آخر بعد أن رأي علي عمر قميصاً أبيض، فقال: البس جديداً وعش حميداً ومت شهيداً.(90) عبارات في مواقف أخري: في السفر: عادة ما يقال للمسافر : تصحبك السلامة، في أمان الله وعندما بستقبل عند عودته: حمداً له على سلامتكك،

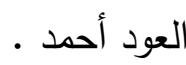

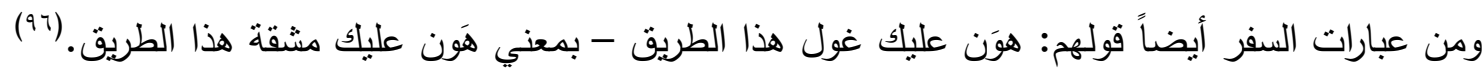

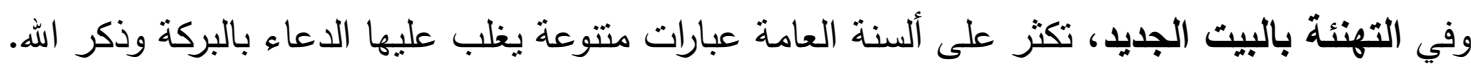

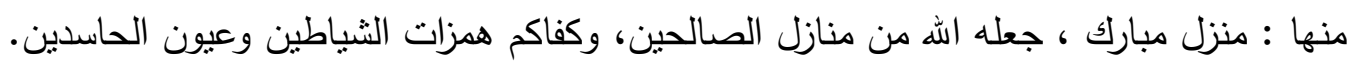
- جعله الله من البيوت المباركة العامرة بذكر الله.

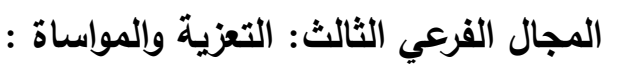

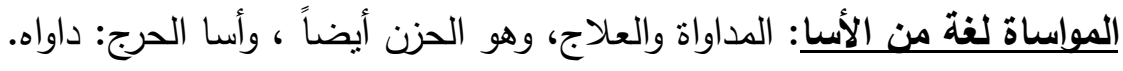

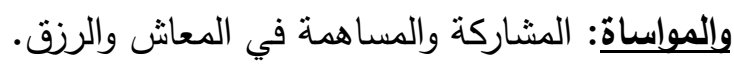

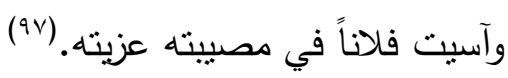

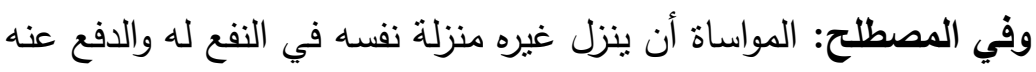

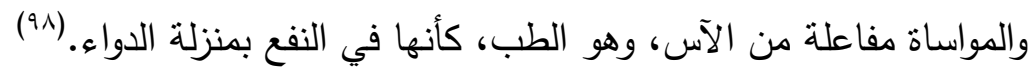


ومن هنا فالمعني المختار لهذا البحث هو: مـا يقال في مواسـاة من وقع في مصيبة، مشاركة له في مصييته ودفعاً للضرر عنه، ومداواة لحزنه ومشاعره.

تختلف الألفاظ والتعبيرات في المواسـاة والعزاء حسب نوع المصيبة، ودرجتها وإن كانت المواسـاة تشمل العزاء،

ومما يقال في الموساة: (خفض عليكم أمرك) أي هون عليك أمرك.

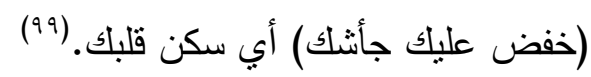

وقولهم: ( للك ما أبكي ولا عَبرةة بي ): أي أبكي من أجلك، ولا حزن للك في نفسي، مثل يضرب لمن يشتد اهتمامه بشأن أخيه، ويؤثره على نفسه. (1..) كما يقال: لله العقبي: لله . (1)

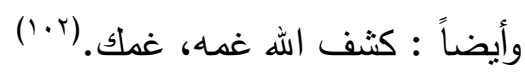
أما العزاء: فهو الصبر عن كلَ ما فقدت، وفعلها عزى يعزي تعزية، وتقول: عزبت فلاناً أعزيه نعزية: أي أسيته وضربت له الأسي، وأمرته بالعزاء فتعزي: أي تصبر ، وتعازي القوم: عزي بعضهم بعضاً.

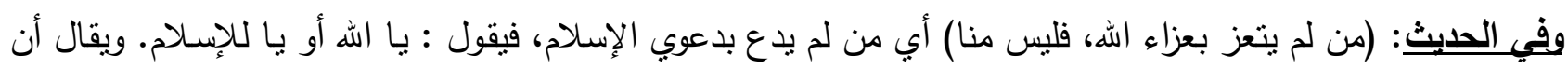

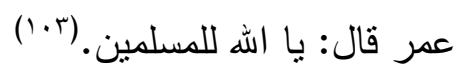
فإذا أصاب المسلم مصيبة تفجعه قال: إنا لله وإنا إليه راجعون.

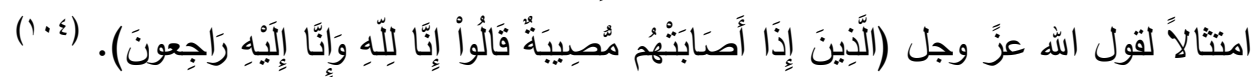
وغير ذلك فليس هناك تعبيرات محددة ثابتة للعزاء، كما قال ابن قدامـة في المغني (لا تعلم في التعزيـة شيئاً محدداً).(1.0) إلا ما أثر عن رسول الله صلي الله عليه وسلم في تعزية ابنته بقوله: إن لله ما أخذ، وله ما أعطي، وكل

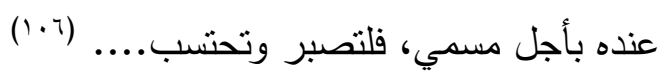
ويدعي للميت بقولهم (اللهم أسد دخلته : أي سد التَّمة التي تركها في دينه). وقولهم في التعزية أيضاً : عظم اله أجرك، وأحسن عزاءك وغفر لميتلك، وألهمك الصبر، وأجزل لنا ولك بالصبر أجراً . (1.v) وفي الرد عليها يختار ما يناسب وقد اشتهر أقوالهم: جزاءً لله خيراً. اعظم الله اجركم أو استجاب الله دعاءكم.

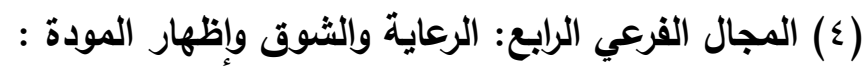
تتوزع عبارات الرعاية والثوق وإظهار المودة حسب السياقات المختلفة ومما جاء من أقوالهم في الرعاية: أنا في جناب فلان : أي في كنفه ورعايته. أنا في جناحه. (1.^) وقولهم: أنا في ذراك: أبي في كنفك.(9.9)

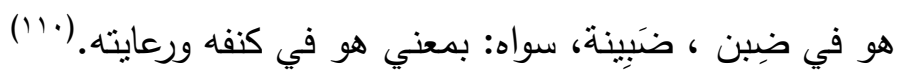

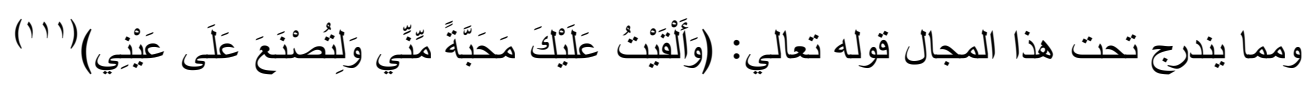
( أي تربي على رعايتي وحفظي للك) ولإظهار المودة والحب يقولون: 
(أنت كبدي وخَلَبي: مثل يضرب للعزيز الذي يشفق عليه).(r'(l) وهو خِلصي وخِني. (1) (1)

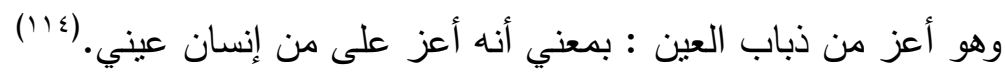
و (لا يفارق سوادي سواده) لا تفارق عيني شخصده.

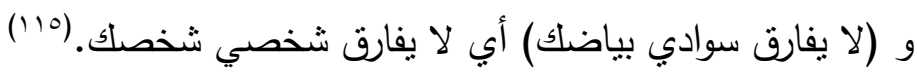

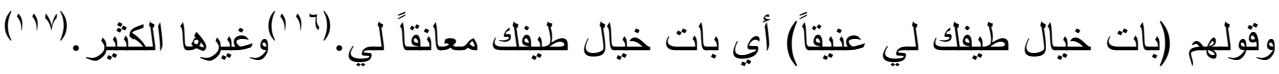
(0) المجال الفرعي الخامس: الاعتذار والاسترضاء تدور ألفاظ وتعبيرات هذا المجال حول الأفعال : (عذر - سامح - عفام)

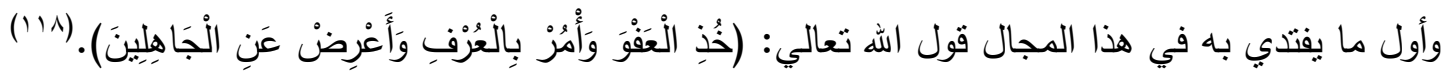

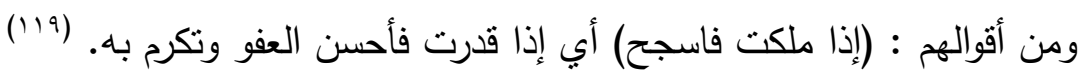
وقد يكون من قولهم دعاء: سامحك الله. ومس ذلك في زقـاق المدق : " ودخـلا الزقاق فرأيـا المعلمـة حسنية الفرانـة تتهال على زوجها جعدة بالثبشب،

فضحك الرجلان، وصاح عباس الحلو مخاطباً المرأة: العفو والرحمة يا معلمة.(r.r.) (طبيعة عباس الحلو "ميال بطبعه إلي المهادنة والمصالحة والتشامح مع نفور من اللجاج والثجار ، ودراية في

أنقائها بالإبتسامة الحلوة واله يسامحك يا عم).('T) ومن الملاحظ استخدام عبارة (سامحك الله، الهه يسامحك) على المستوي الطبقي الأعلي والأدني معاً، وإن كانت في المستوي الأدني تستخدم مع أسلوب من النداء بلفظ للقرابة، كنوع من التودد.

(المجال الدلالي الرابع : التلطف) التلطف لغة من اللطف - لطف، وتلطف ، واللطيف: من صفات الله تعالي واسم من أسمائه. ومن معانيه الرفق: فاللطيف الذي يوصل إليك إربك في رفق، واللًّف واللًُف: البر والتكرمة ، والتحفي ، وفي العمل: الرفق فيه.

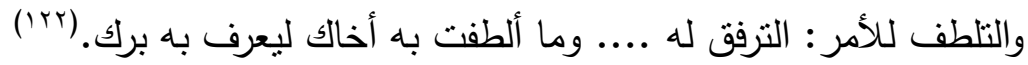

وفى القرآن الكريم: يتلطف: يترفق. (rr)

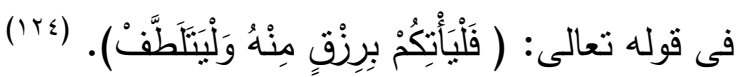
والتلطف قد يحمل معنى الأضداد: ففى اللسان: اللطيف من الأجرام والكلام: ما لا خفاء فيه.... وأيضًا: اللطيف من الكلام: ما غمض معناه الاهن وخفى. من خلا ما سبق نستتتج أن معنى التطلف يدور حول معنى عام واحد وهو الترفق كما يقول ابن فارس فى مقاييس اللغة (مادة لطف) (rol) سواء أكان هذا فى الكلام أو العمل أو الأمر من الأمور ، وفى التعامل، مع احتمال دقة المعنى ووضوحه أحيانًا وخفائه فى سياقات أخرى.

التلطف اصطلاحيًا: التلطف: تحسين اللفظ. (r) ويعرفه ستيفن أولمان بأنه ضرب من حسن التعبير فيقول: "وحسن التعبير وسيلة مقنعة بارعة لتلطيف الكلام وتخفيف وقعه" . (IrV) 
وقد فطن العرب القدماء إلى هذا المعنى وألفوا فيه الفصول بل وأفردوا له الكتب. وممن قال فى ذلك الثعالبى الذى عقد

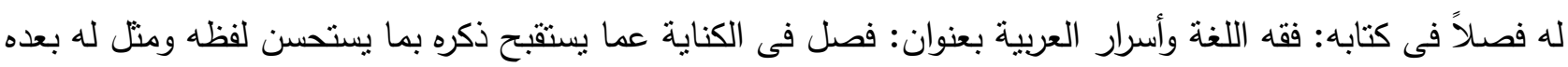
أمتلة من القرآن وكلام العرب، ثم أفرد له كتابًا بعنوان [الكناية والتعريض] وقدم له بقوله: " إنه كتاب... فى الكنايات

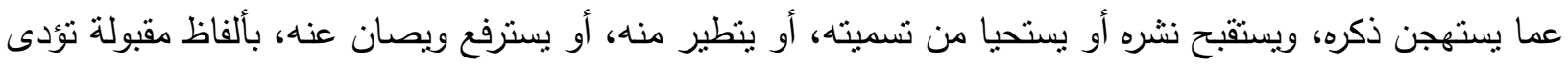
المعنى، وتقصح عن المغزى، وتحسن القبيح، وتلطف الكثيف، وتكسوه المعرض الأثيق فى مخاطبة الملوك، ومكاتبة

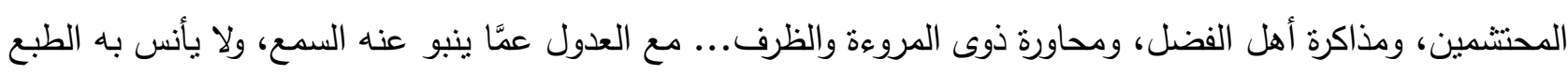

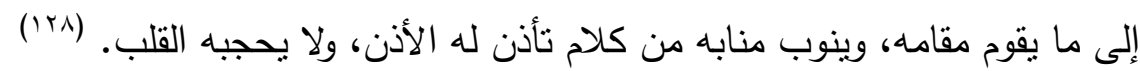
ويشير نص الثعالبى السابق إلى دوافع استخدام الكناية والتعريض (أو التلطف بالمصطلح الحديث) وأيضًا المواقف التى ولى ولى يحسن فيها استخدامها فالتطير، والقبح، والاستحياء. والصون كلها دوافع لتغيير الأسلوب وتحسينه، فى مخاطبة أنواع خاصة من الناس ومراعاة للاحتشام والآداب، والمشاعر • وهذا ما أثنار إليه أولمان أيضًا عندما يعلل هذه الظاهرة بقوله:

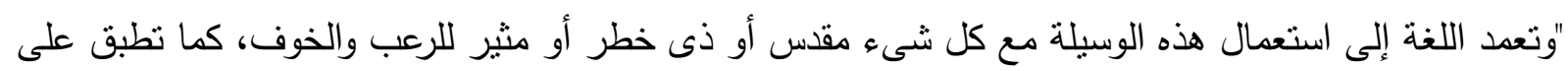

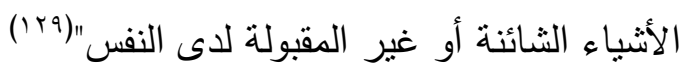
ولنتعب الموضوع وايجاز البحث سأتتاول نماذج منه فى القرآن الكريم وفى كلام العرب مبينًا الدافع أو السبب والموقف الذى يقال فيه من خلال تحليل هذه النماذج. أولاً: التلطف فى القرآن الكريم:

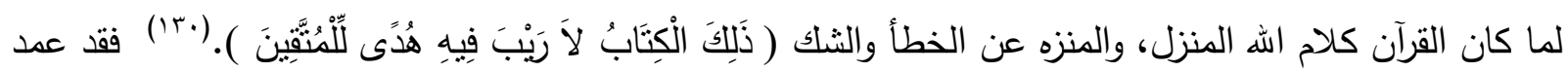
إلى التلطف فى كثير من المواقف والآيات التى لو ذكر بلفظ غير ما جاء فى القرآن لكان مما بدور على ألسنة الناس من مستقبح أو يستحى منه.

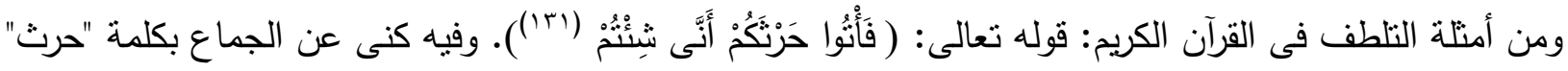

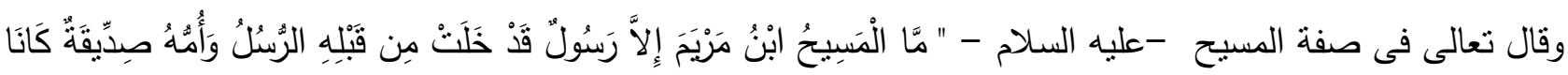

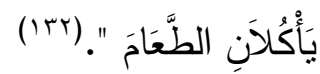

• فكنى بأكل الطعام عن الغائط والبول، لأنهما بسبب منه إذ لابد للآكل منهما، والعرب تسمى الثىى باسم الثىء إذا

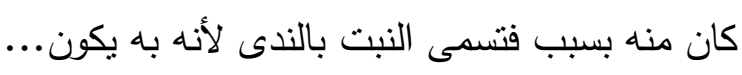

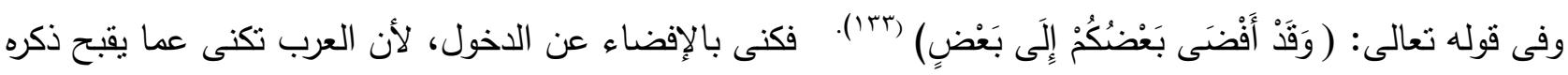
فى اللفظ" . (1) و والهدف والدافع من هذه الكنايات هو الترفع عن ذكر ما يستقبح وعن الفاحش احتشامًا وتلطفًا باستخدام حسن التعبير واللفظ المؤدى إلى المعنى. أما المواقف التى سبقت فيها الآيات السابقة فهى مما يستحى الإنسان من ذكره تأدبًا ومن فعله دون ستر مراعاة للآداب والنفس والمشاعر • ومما ورد من هذا النوع من التلطف فى الحديث الثريف: ماروى أنه مر - عليه السلام - بأنجشه وهو يحدو بنساء

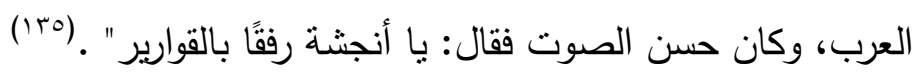

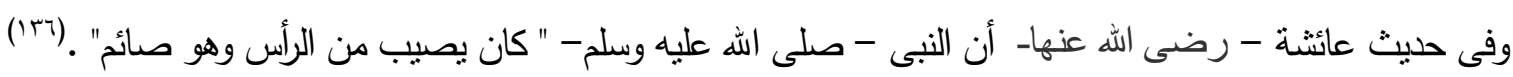
فكنَت عن القُبلة بالمكان وهو الرأس. 
جاءت الكناية فى الحديث الأول بأحسن لفظ مما يعبر عن رقة النساء وسهولة تأثرهن بالحسن فإذا راعيت كل ذلك احتشامًا وتلطفًا وتأدبًا لم يكن هنالك أدق من لفظ القوارير التى لا نستعمل إلا مع الحرص الثديد. وكذلك فى الحديث

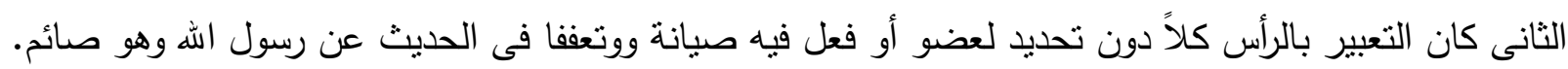
ثانيًا: التلطف فى كلام وأساليب العرب: يعدد العربى إلى استخدام التلطف فى الأساليب والألفاظ للتفاؤل ودفع التشاؤم والخوف من مرض أو شدة أو مصيبة. وقد يكون استحياء وصونًا لعضو أو فعل عن الذكر المباشر، أو احترامًا وتقديرًا وتقديسًا. وقد قسمت أساليب

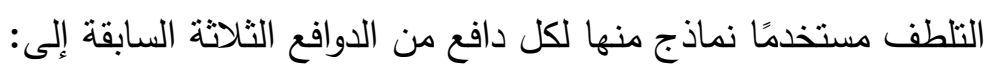
1- التلطف: دفعًا للتشاؤم والخوف إذا أراد العرب ذكر الموت: قالوا: " استأثز اله به"، " أسعده بجواره" " نقله إلى دار رضوانه ومحل غفرانه" ،

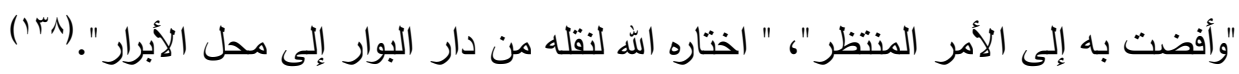
فالموت من أكثر ما يخاف منه الأنسان ويتشاءم من ذكره، ولذلك عدل عن ذكره، ومال إلى التلطف فى الأساليب

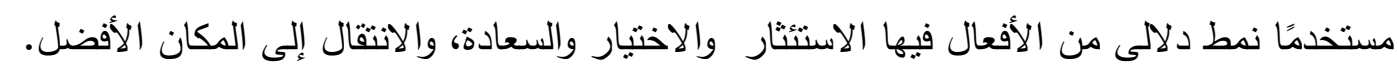
وفى التعبير عن الشيب:

قالوا: " أقبل ليله" ـ "ونور غصن شبابه" و "لاح الأقحوان فى بنفسجه" فالثيب مما يتحاثاه الإنسان ولا يريد أن يقترب منه ومن ثم لجأ العرب إلى استخدام المفارقة اللونية للتعبير عن هذه المرحلة العمرية فاستخدام الليل مع كونه أسود إلا أنه يدل على نهاية اليوم والحياة، والنَّزّر مع تشابهه فى اللون بالثيب إلا أن الغصن إذا كثر فيه النور فقد اقتربت نهاية قطف ثماره، أما لون الأقحوان فهو أبيض فى مفارقة مع لون البنفسج. ولذا استخدموا: النسر كناية عن الثيب ، لبياضه في ريشه.

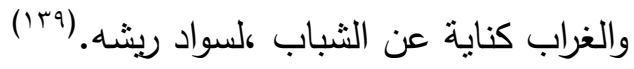

$$
\begin{aligned}
& \text { وفى الكناية عن الأمراض والعيوب: } \\
& \text { يقال: "كان جذيمة أبرص، فكنى عنه بالَوََّّاح والأبرش" }
\end{aligned}
$$

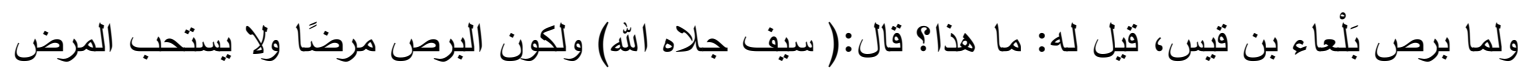

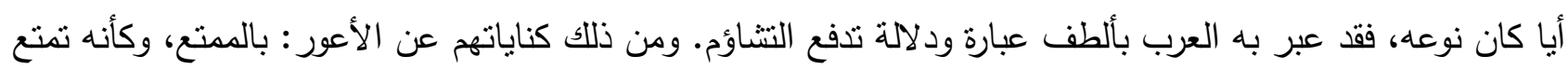

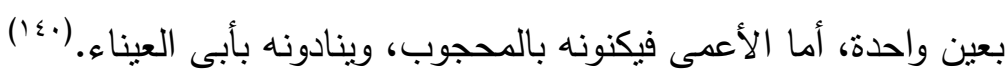
ويغلب على هذا النوع من أساليب التلطف والكناية ظاهرة التضاد أو المفارقة اللغوية كما فى قولهم عن اللديغ: السليم. وعن الأعمى: البصير وعن المهلكة أو الصحراء: المفازة.

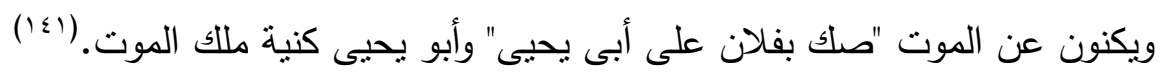
r - التلطف: استحياء وصونًا للعضو والفعل:

يضم هذا المجال كل ما يتعلق بالمرأة والعلاقة الحميمية مع الرجل والأعضاء والعورات التى بيتحيا من ذكرها مباشرة فى الثقافة العربية. "والعرب تكنى عن المرأة بالنعجة والثشاة والقلوص والسرحة والحرث والفراش، والعتبة، والقارورة، والقوصرة،

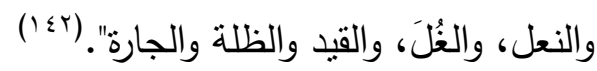


ولكل لفظة من الألفاظ السابقة دلالة خاصة ترتبط بموقف أو معنى جانبى يرتبط بالمرأة وباللفظ المكنى به: ومن ذلك الكناية بالسَّرحة: يقول الثعالبى: "أما الكناية بالسرحة وهى شجرة - فكما قال حميد بن ثور :

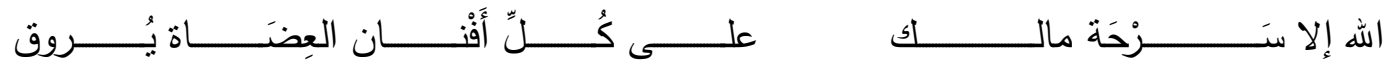
وإنما كنى عن امرأة ماللك بسرحة مالك أحسن كناية وعبر عن اتقانها فى الحسن على سائر الغوانى أحسن عبارة.

ففى السرحة: الظل والراحة، والثمر وانتشار الأغصان كلها معان تصدق على المرأة التى يسكن إليها.

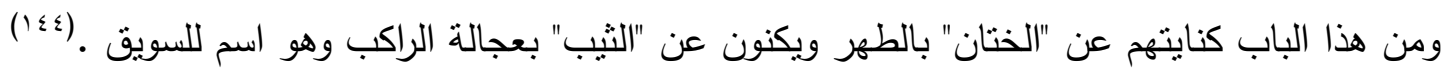

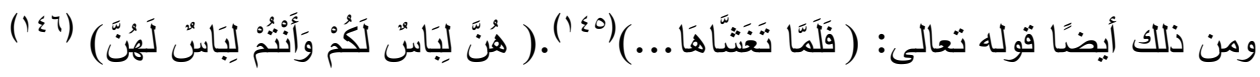
وكلاهما كناية عن ابتغاء الثهوة والتماس اللذة وطلب النسل، فهى من أحسن وأجمل وألطف الكنايات كما يقول

\section{r- التلطف احترامًا وتقديرًا:}

ويكون ذللك غالبًا فى المناداة بالألقاب والأوصاف المستحقة لكل صاحب مكان وقرابة ومن ذللك "إقامة العم مقام الأب، وإقامة الخالة مقام الأم، وهو ما عقد له الثعالبى فصلاً من كتابة (فقه اللغة و سر العربية) ممثلا بقوله

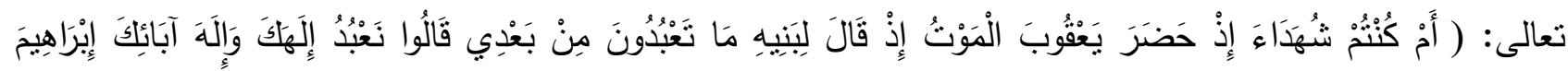

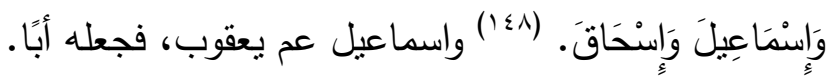

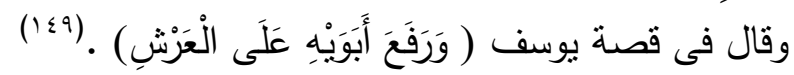

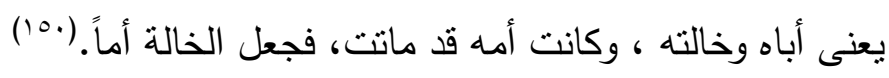
ويدخل ضمن هذا المجال كنايتهم عن موت الرؤساء والأجلة والملوك: "انتقل إلى جوار ربه، ، واستأثر الله به"

وبرى بعض الباحثين أن كثرة الألفاظ الدالة على الحب، والعسل وغيرها من الأشياء التى يحبها الإنسان تدخل فى هذه الباب وإنها لثدة ولوع المجتمع العربى بما تدل عليه هذه الألفاظ، وإنتقال المجاز إلى حد الاسم فينتقل إلى وعلى

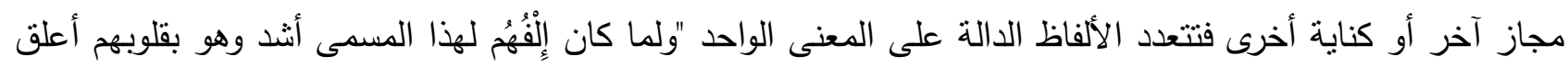

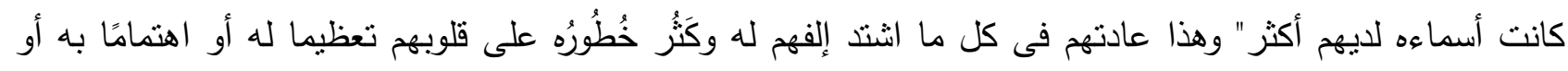
محبة له.... وقد اجتمعت هذه المعانى الثلاثة فى الحب فوضعوا قريبًا من سنتن اسمًا وهى: المحبة، والعلاقة، والهوى ،

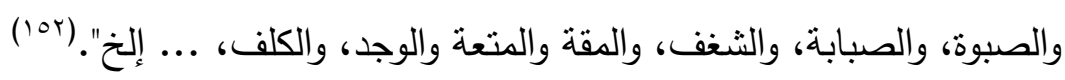
ومن خلال استقراء أمنتلة هذا المجال نلحظ وضوح بعض الظواهر اللغوية منها ما ذكرته سابقًا من ظاهرة التضاد (الأضداد) بإستخدام المعنى والكناية بمضاده تفاؤلاً أو دفعًا للنتاؤم من المعنى الأول. كما فى الكناية عن أن

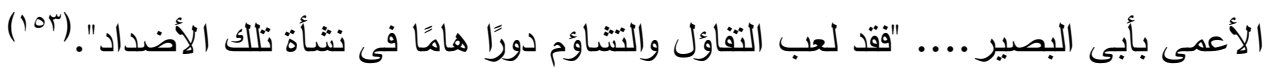
ومن الظواهر اللغوية أيضًا بلى الكناية أو المجاز وانتقاله إلى حد الاسم لاشتهاره بين الجماعة اللغوية ومن ثماءة تعددت وكثرة الكنايات للثىء الواحد. 
يتتاول هذا المبحث ما ورد فى البحث من عبارات وألفاظ التحية والمجاملة بالتحليل اللغوى حيث يناقش التعبيرات الاصطلاحية الواردة والمستخدمة وتحليلها، وكذلك اللغة الإشارية والتعبيرات الجسدية المصاحبة للغة التحية ، كما يحلل الظاهر والسمات اللغوية التى بررت فى هذا الاستخدام اللغوى ، وأخيرًا يحدد المرجعيات المختلفة التى اعتمد عليها هذا النمط اللغوى المرتبط بالمجتمع. 1. التعبيرات الاصطلاحية : بعرية

يكثر تردد بعض التراكيب اللغوية فى لغة التحية وعبارات المجاملة بعضها بمكن تصنيفة على أنه تركيب ثابت أو كلاشيه، وهذه التراكيب الثابتة لا تتغير إذا وردت فى سياقها اللغوى أو المقالى كما بقال فى بعض البيئات اللغوية لمن ينتهى من الصلاة :( حرمًا ).. ويحتم علينا العرف اللغوى والاجتماعى أن نرد ردًا بعينه وهو قولنا : ( جمعًا

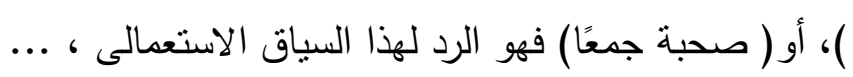

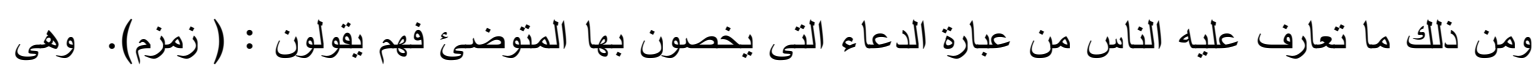
تعنى أن المتكلم بدعو للمخاطب المتوضئ بالوضوء من ماء زمزم ، أو الثرب منه ، مما يعنى: الحج أو زيارة الأماكن المقدسة ، والرد على هذة العباره لاتخضع للعملية الابداعية التى تمكن السامع من الاجتهاد فى الرد ، وتأليف عبارة

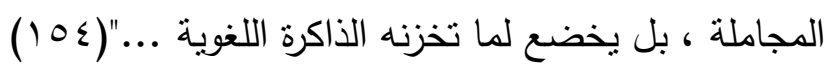
ومن هذه التراكيب الثابتة عبارات تشميث العاطس: يرحمك الله- وردها ، والاعاء لمتتاول الطعام : هنينًا مرينًا وردها ونعيمًا... الله ينعم عليك .. إلخ من هذه التراكيب.

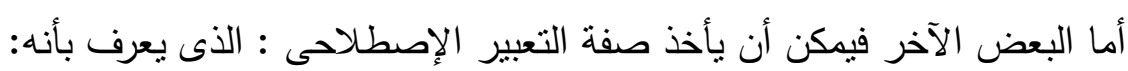
"وحدة لغوية تتكون من كلمتين أو أكثر تدل على معنى جديد يختلف عن المعانى التى تدل عليها الكلمات

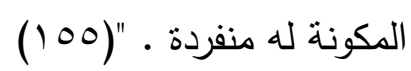
وقد تتوعت هذة التعبيرات ولوحظ أنها تتنمى إلى أكثر من مجال سياقى ومقامى، ومنها ما جاء مباشرًا

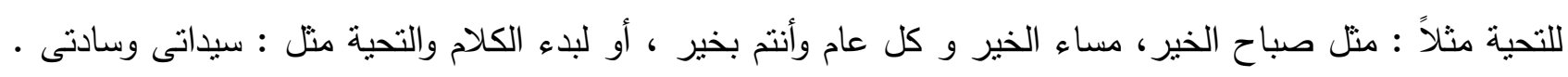

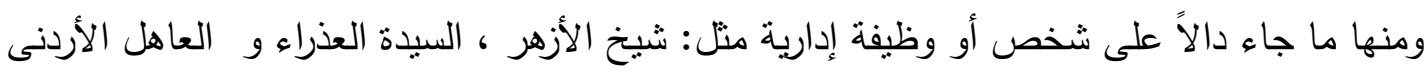
ومنها التعبيرات الايحائية والضمنية الدلاكة: نحو: الإمام الأكبر - صاحب الفخامة، فالتعبيران يدلان دلالة ضمنية على كل صاحب مكانة كبيرة فى قومه مع تخصيص الدلالة الدينية أو السياسية ، وتبقى دلالة السياق اللغوى التى تحدد المقصود الدقيق للتعبير ، فالإمام الأكبر يعنى شيخ الجامع الأزهر ، والذى يترادف مع التعبير المذكور سابقًا، أما تعبير صاحب الفخامة ، فإذا صاحب سئ سياق

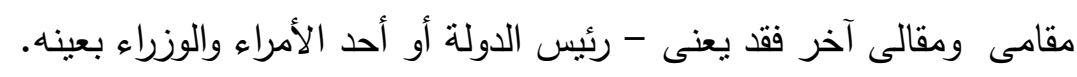

\section{ومنها التعبيرات السياقية :}

التى ثرتبط بسياق مقالى أو لغوى محدد مرتبط بمناسبات معينة فى لغة التهنئة والتحية والمجاملة مثل:

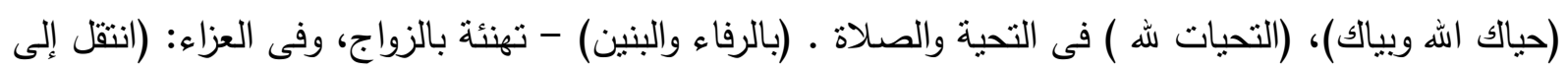

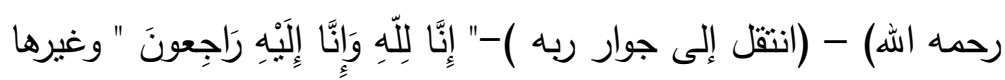




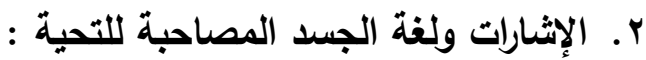

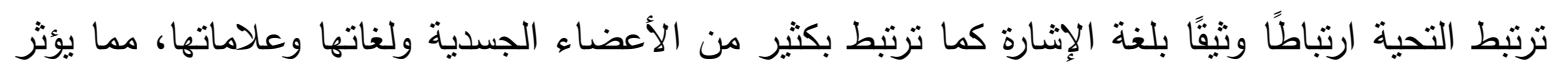

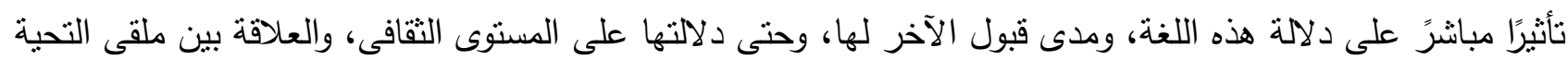

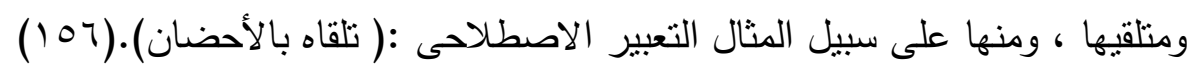

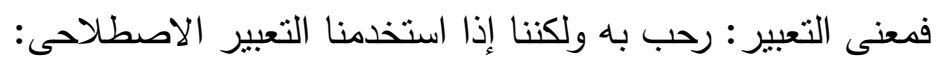

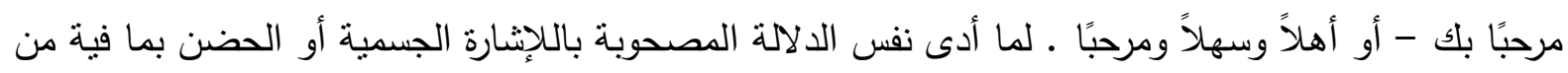
دلالة خاصة على حفاوة الترحيب وحرارته.

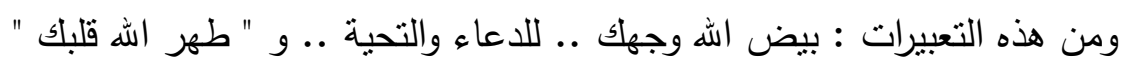

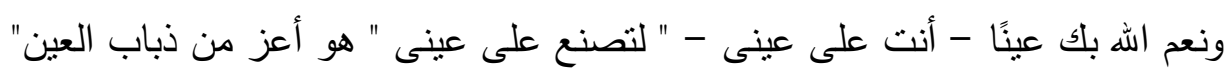

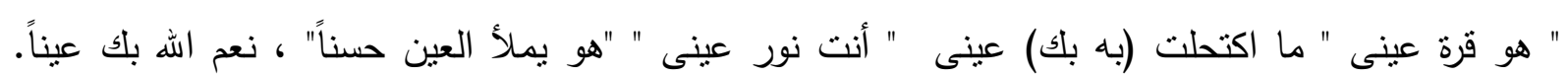

ومن الملاحظ أن ورود لفظ العين في عبارات المجاملة والتحية بكثرة تغلب علي باقي الأعضاء، يليها الوجه

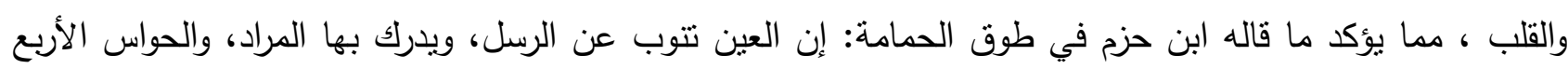

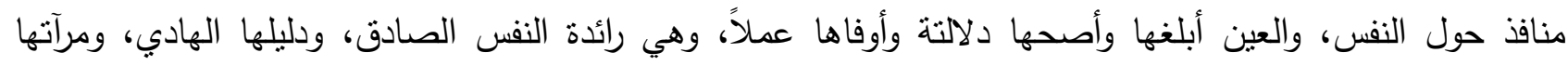

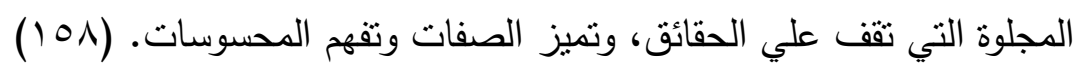

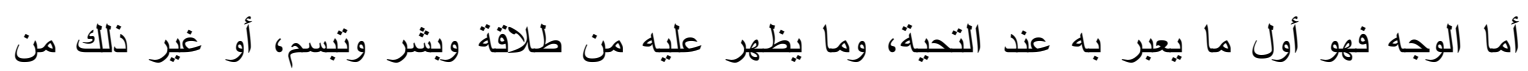
العلامات السيميائية الدالة علي المشاعر بين أطراف التحية.

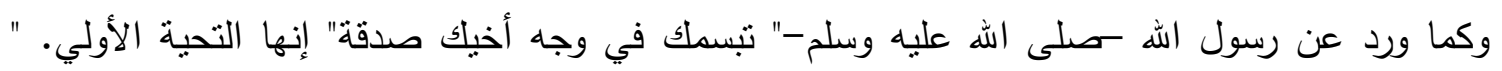

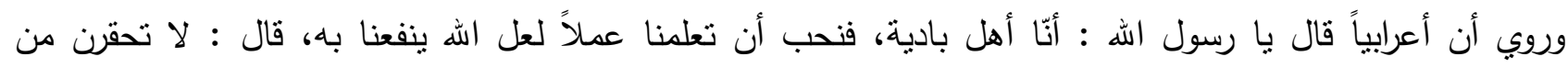

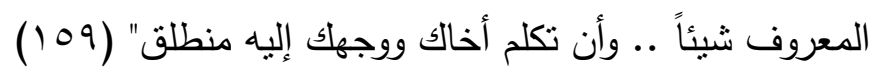

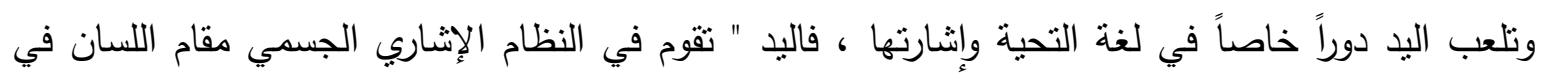

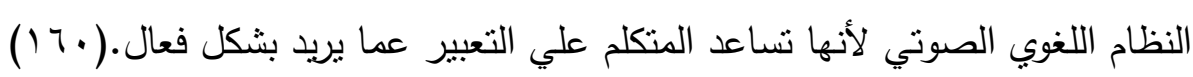

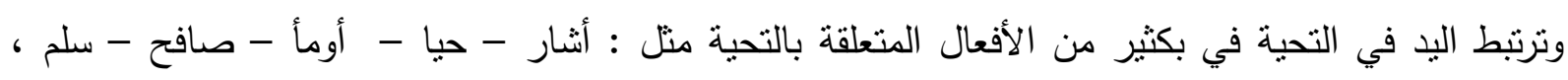

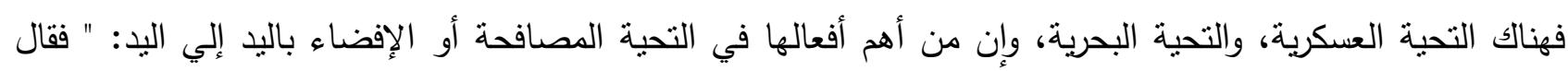

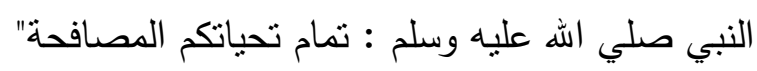

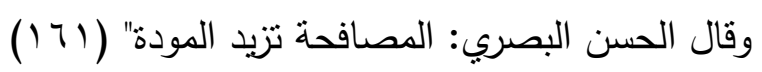

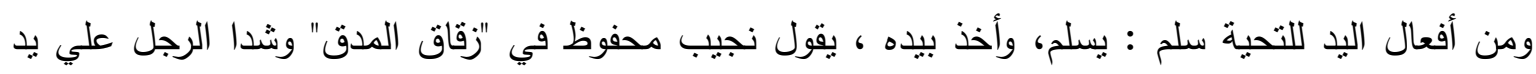

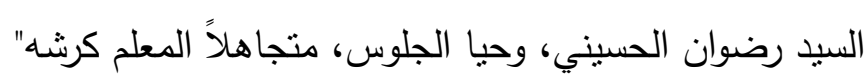

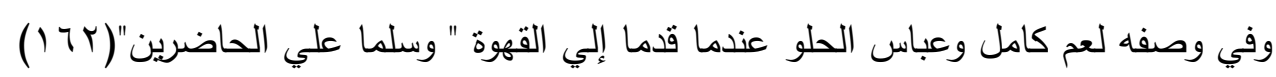

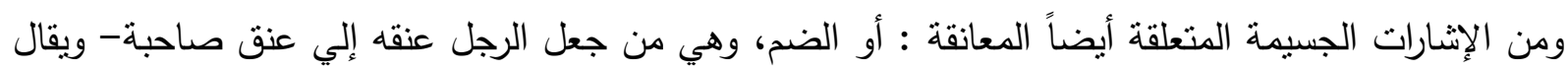

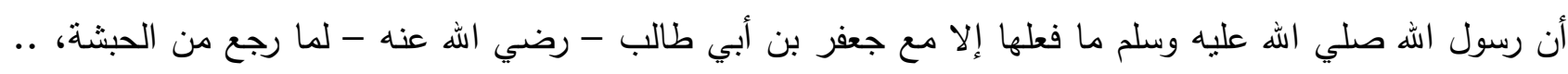

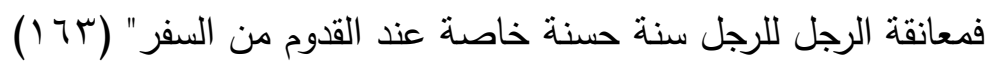
وكذلك تقبيل اليد والرأس تديناً وإكراماً واحتراماً، ولكن ذللك يخضع للأعراف والعادات الاجنة الاجماعية من بلد إلي آخر . 


\section{(r) السمات والظوالهر اللغوية للغة التحية:}

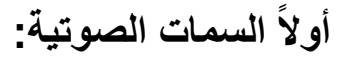

يمثل الإبدال الصوتي أو القلب المكاني للأصوات " إحدي الوسائل التي يلجأ إليها المتكلم لتجنب اللفظ المحظور، ويأتي بلفظ آخر محسن عن طريق الابدال أو التحريف الصوتي مثل : بك الرجل المرأة يبكها بكاً، وهكها

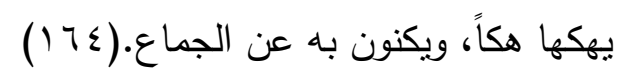
الصورة الآخري للسمات الصوتية هو مراعاة علو الصوت ودرجته في الصناداة وهذه تخضع للأعراف الاجتماعية والدينية، وأيضاً تعبر عن المستوي الطبقي والثقافي لمستخدم المناداة والتحية، وقد نُهي المسلمون عن رفع

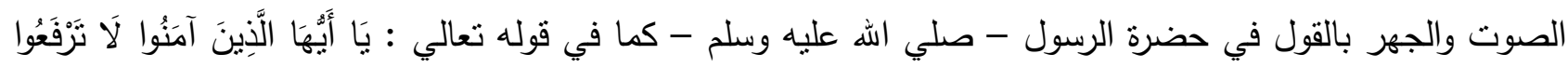

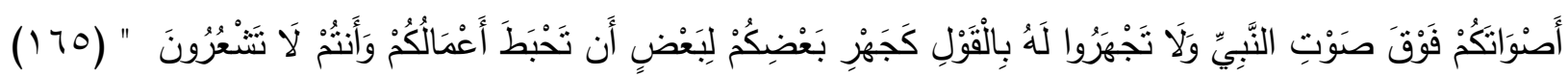
ثانيا: السمات الصرفية وإلتركيبية لعبارات التحية والمجاملة: بالئ كثيراً ما تعدد الجماعة اللغوية إلى - اختيار بعض الألفاظ الصرفية الأكثر تعبيراً في لغة التحية وخاصة في في المناداة، ومنها إدخال ( أل ) التعريف على العلم نحو: العباس - الفضل - المنصور ؛ وذللك للتفخيم والتعظيم.

- استخدام صيغة التصغير في الأعلام للترقيق والتودد وإظهار الرحمة، كما فى عمير .. النغير .. جبير . - غلبة بعض الصيغ الصرفية فى ألفاظ التقدير والاحترام المصاحب للاسم العلم كصيغة فعيل : أمير عظيم ، وصيغة فعالة: نيافة ، فخامة ، علامة . - تحول الصيغ الصرفية ، كانتقال صيغة ( السيد ) التى كانت تخص دلالتهاه لتها على من كان من السلالة النبوية

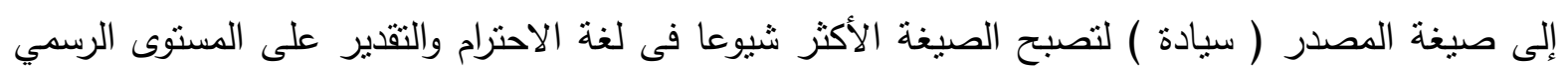
مثل سيادة الرئيس ، وسيادة القاضى، وسيادة الوزير .... ـ أما من الناحية التركيبية: فيغلب على عبارات لغة التحية والمجاملة الايجاز الثديد أحيانا كما فى التعبيرات الثابتة ( حرما - زمزم - مرحبا - اهلا وسهلا - شفاء وطهورا ...

ثالثا :الملامع الالالية للغة التحية: - ارتبطت عبارات التحية بألفاظ القرابة سواء أكان ذلك فى المناداة نحو : يا عم ، ياخالي، ياخالتي، ياستي، يا ابن

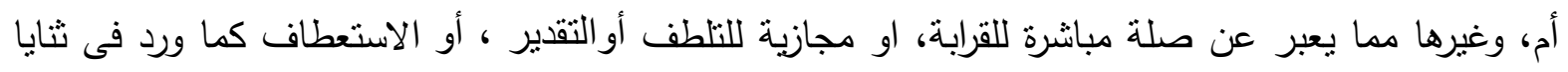
البحث، بما يكثف عن استخدام المستوى الطبقى والثقافى والسياق الذي استخدم فيه.

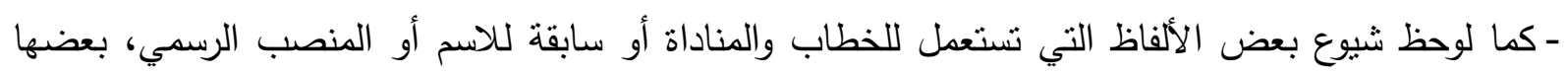
بستعمل فى اللغة الرسمية، والبعض الآخر فى لغة المتقفين، ومعظمها فى اللغة الدارجة وبين معظم الطبقات

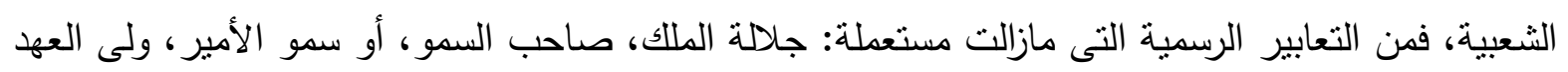

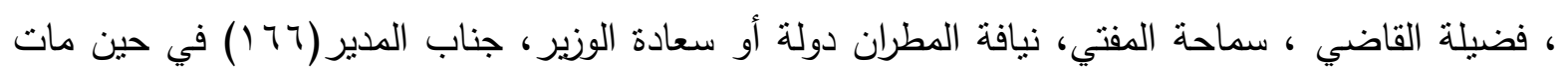
استخدام القاب منل: خديوي، اتابك، الخليفة، الوالي. - في لغة التلطف يغلب الطابع المجازي على الاستخدام ، وأيضا اسلوب الكناية أو التعريض بكلمات أو عبارات

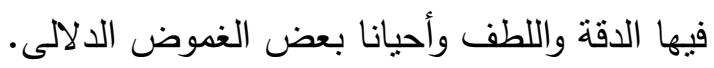




\section{رابعا: مصادر ومرجعيات لغة التحية:}

- يشكل المرجع والمصدر الديني أغلب عبارات لغة التحية، وبخاصة فى الديانة الإسلامية بمصدريها القرآن الكريم والسنة النبوية، وهذا ما يفسركثرة ورود كلمة السلام كتحية فى القرآن الكريم، وأحاديث الرسول - صلى الله عليه وسلم - وإن كانت الديانة المسيحية تشكل جانبا آخر من مرجعيات لغة التحية وإن اقتصر على بعض الألفاظ واللقاب مثل نيافة، السيد المسيح، السيدة العذراء، وفى التحية : سعيدة، ...ويومك سعيد.

ـ المصدر الثاني المرجعية السياسية والإدارية : والتي أفرزت من الألقاب والرتب التي تستخدم فى المناداة أو المخاطبات الرسمية والمعاملات الدولية، مثل : العاهل، الأمير، ولي العهد، فخامة الرئيس،.....إلخ. بالإضافة الإنة

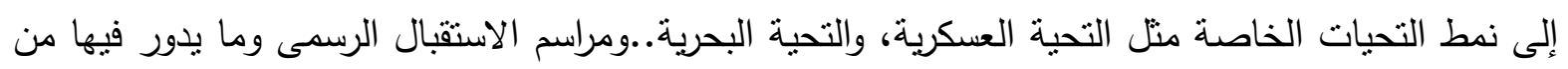
عبارات خاصة بالتحية. - المصدر الثالث المرجعية الثقافية والثعبية: التي ترتبط بتقالبد كل مجتمع وعاداته، وكل طبقة أو حرفة من طبقات المجتمع وطوائفه، واختيارهم واستعمالهم لنمط معين من التحية، واستخدامهم لألفاظ وألقاب خاصة بكل فئة متلما لا حظنا ذلك فى عبارات النداء والتحية فى رواية زقاق المدق منل: يا معلم كرشة.. المعلمة حسنية..

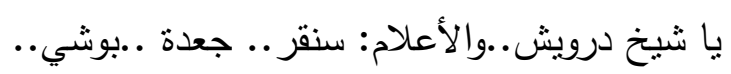
ومن أمثلة ذلك شيوع لقب معين مرتبط بفئة لغوية ما مثل لقب (شيخ ) فى جبال لبنان مثلا، ولقب (حاج) لكل زائر فى مكة والمدينة المنورة، ولقب (شيخ) فى التقافة الشعبية المصرية. نتائج البحث وتوصياته: من خلال بحث واستقصاء لغة التحية والمجاملة فى الثقافة العربية توصل الباحث إلى :

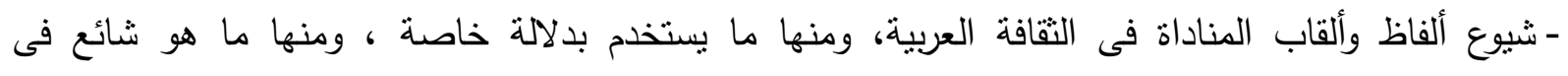
الاستخدام على المستوبين الرسمى والثعبى. - فى مجال التحية غلبت عبارة السلام والتحيات على الاستخدام فى لغة القرآن وعلى المستوى الرسمى والثعبى، مرتبطة بأفعال خاصة مثل حيا ، سلم ، صافح، عانق ، ودع ، استقبل...

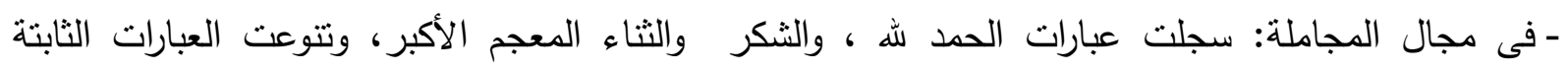
والتعبيرات السياقية لتشمل التهنئة بكل مواقفها، والتعزية والمواساة، وكذلك الرعاية والشوق، والاعتذار والاسترضاء. - فى مجال أساليب التلطف غلب استخدم الألفاظ الحسنة أو المحسنة تحاثيا للألفاظ والأفعال التي يستقبح ذكرها احتشاما وتادبا واستحياء، وسيطر اسلوب المجاز والكناية مما أدى إلى كثرة المترادفات أو الكنى والألفاظ الدالة على معنى واحد. - ارتبط استخدام لغة خاصة بالتحية والمجاملة بالإشارات الجسمية، واحتلت العين والقلب النصيب الأكبر من معجم ألفاظ وتعبيرات التحية والتلطف. - كما ارتبطت لغة التحية ارتباطا وثيقا بألفاظ القرابة المختلفة وخاصة فى مجال المناداة والألقاب. - كثف التحليل اللغوي لعبارات التحية عن شيوع مصاحبات لغوية خاصة لأفعال التحية، والإشارات الجسمية الخاصة بها. 
- ومن خلال استقراء عبارات التحية نلحظ وجود بعض الظواهر اللغوية مثل ظاهرة التضاد (الأضداد) باستخدام

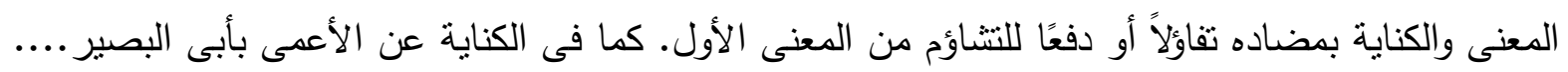
فقد لعب التفاؤل والتثاؤم دورًا هامًا فى نثأة تلك الظاهرة. - تتوعت مصادر ومرجعيات لغة التحية منها المجعيات الدينية ولها الغلبة في وفرة الألفاظ والعبارات المستمدة منها ، وكذلك المرجعية السياسية والإدارية، والمرجعية النقافية والثعبية.

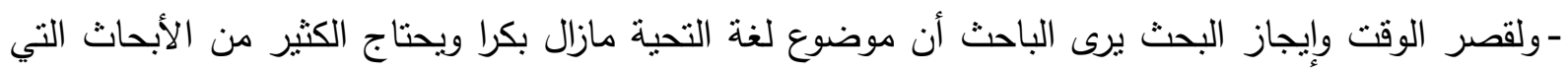
تكثف عن أصوله وقوانيه ومستوياته فى الاستخدام قديما وحديثا.

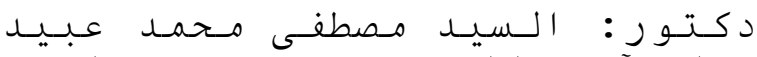

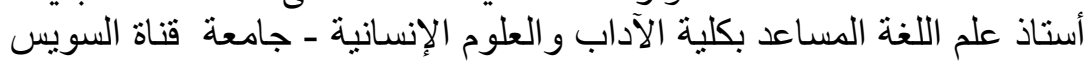

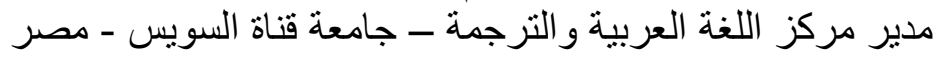




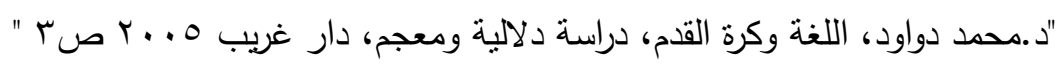

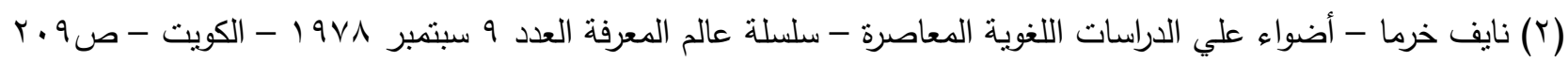

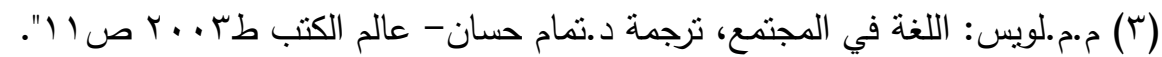

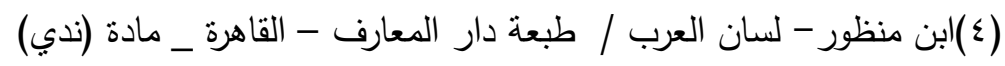

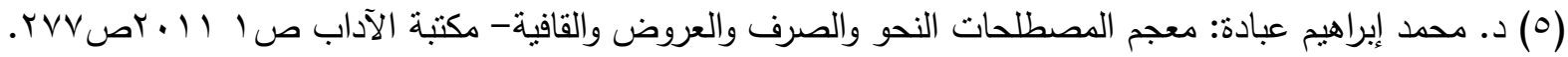$$
\text { (†) (ך) لسان العرب مادة (دعا). }
$$

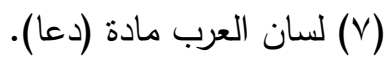

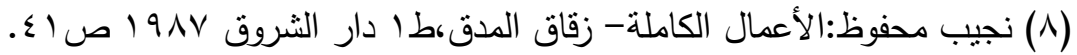

$$
\begin{aligned}
& \text { (9) الأعراف (11) (1). } \\
& \text { (1) (1) الإسراء (1) (1). }
\end{aligned}
$$

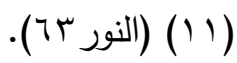

$$
\begin{aligned}
& \text { (Y) }
\end{aligned}
$$

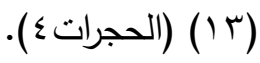

$$
\begin{aligned}
& \text { ( ( ا ) (الحجرات ب). } \\
& \text {. } 9 \leq 0 \text { (b) (10) } \\
& \text { (7 1 ) ابن كثير }
\end{aligned}
$$

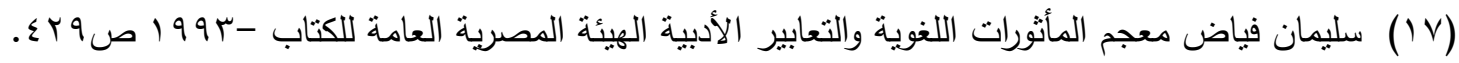

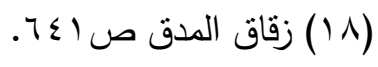

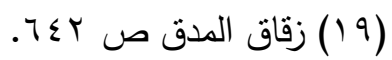

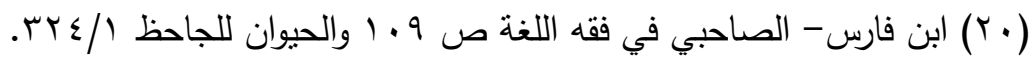

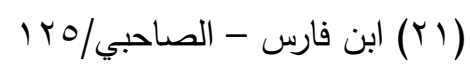

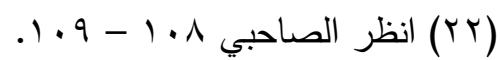

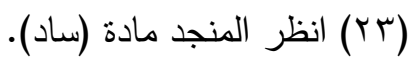

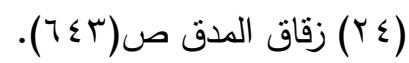
(Yo) (ب0) انظر المنجد مادة شيخ/شاخ. (Y7) انظر د.محمد داود - المعجم الموسوعي للتعبير الاصطلاحي.

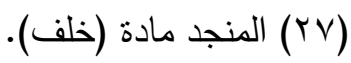

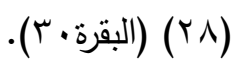
. (ص (rq) (rq)

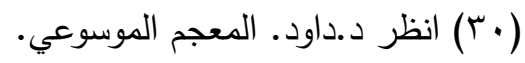
(T) المنجد مادة (خلف) وانظر د.داود المعجم الموسوعي للتعبير الاصطلاحي.

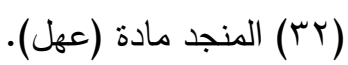
(זr) (ب) د.داود المعجم الموسوعي للتعبير الاصطلاحي.

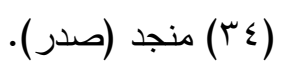


( ) (ب0) د.داود. المعجم الموسوعي للتعبير الاصطلاحي. (דب) انظر المعجم الموسوعي للتعبير الاصطلاحي، وهناك تعبيرات أخري منها: سلطان زمان، سلطان غشوم خير من فتنة تدوم.

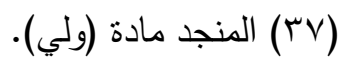

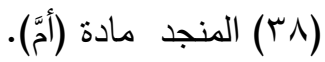
(؟q) شبكة المعلومات الدولية ويكبيديا.

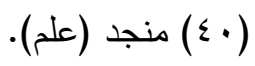
(1) (1) شبكة المعلومات الدولية ويكبيديا.

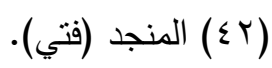

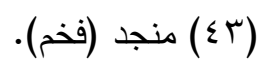
(

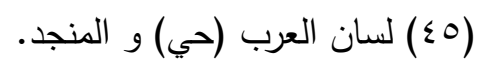

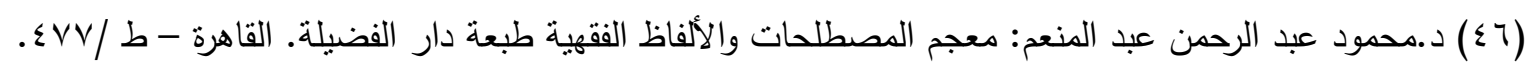

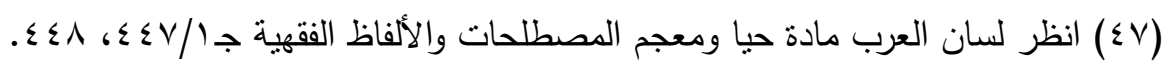

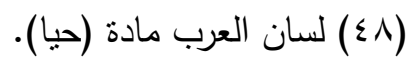

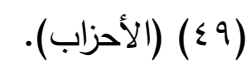

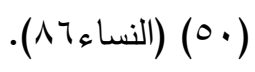

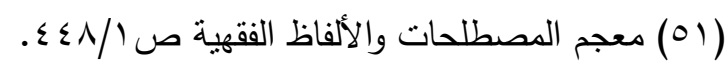

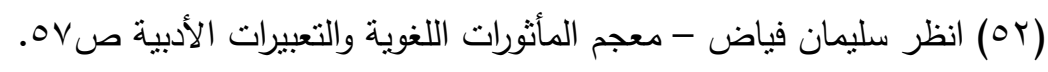
.11) (00) لسان (حيا).

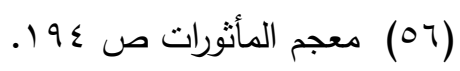

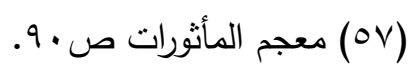
(01)

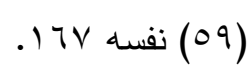

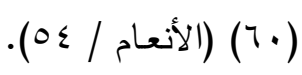

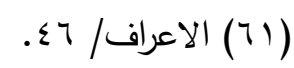

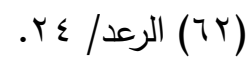

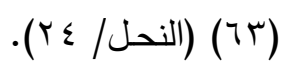

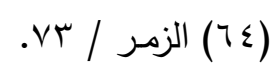

(70) ينظر : المنجد، ولسان العرب/ رحب.

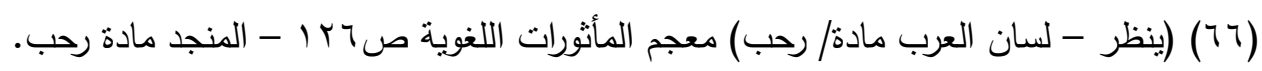

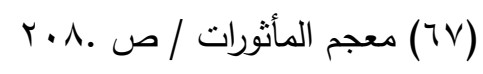

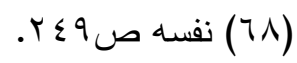

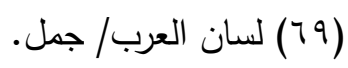

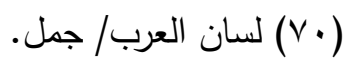




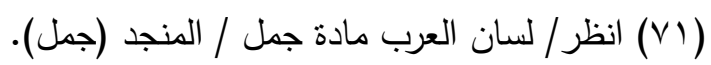

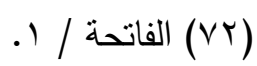

. / الأنعام (VT)

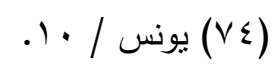

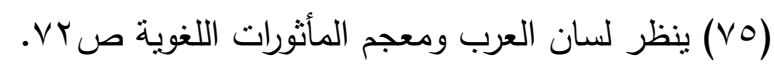

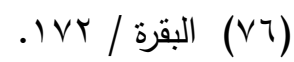

انظر لسان العرب/ شكر ( VV)

ل لسان العرب - جزي. (V^)

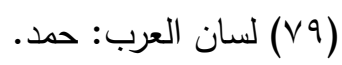

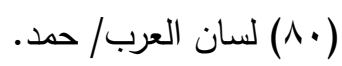

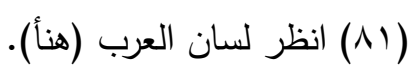

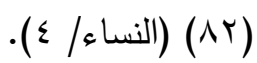

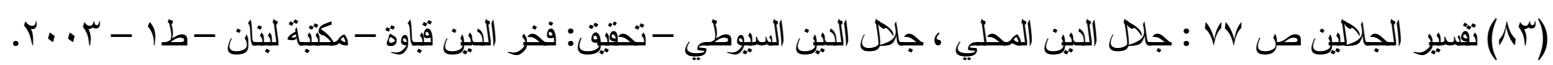

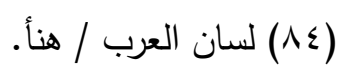

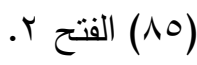

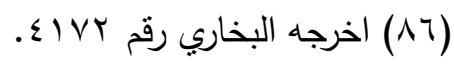

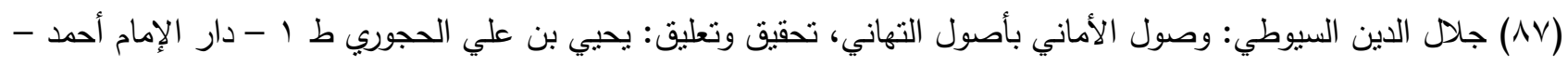

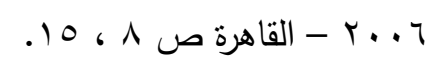

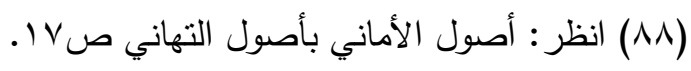

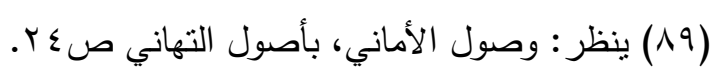

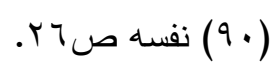

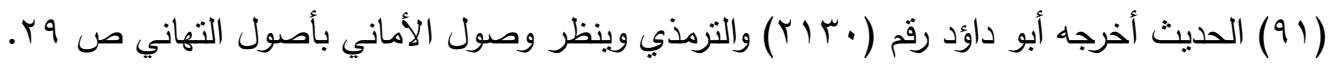

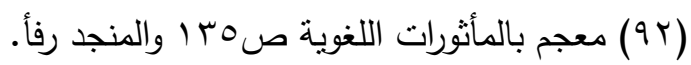

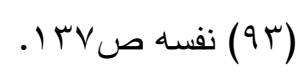

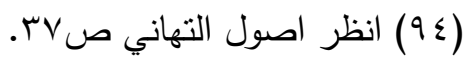

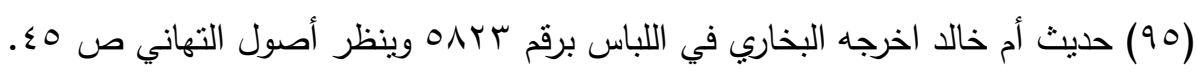

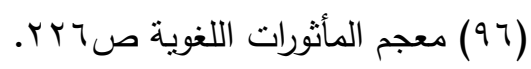

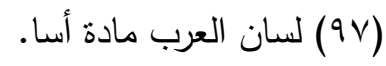

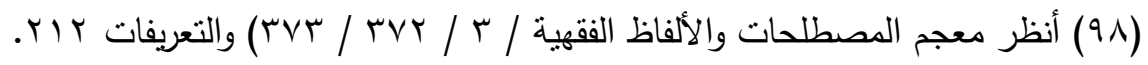

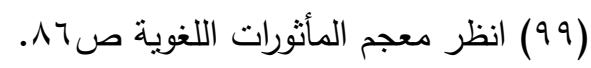

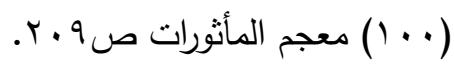

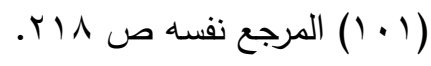

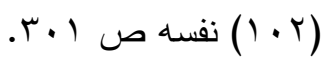

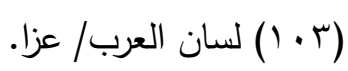

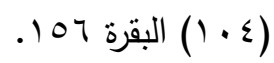




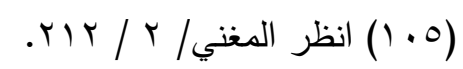

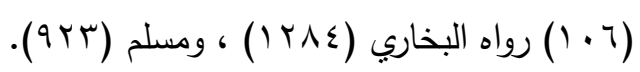

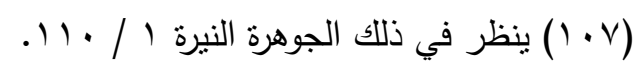

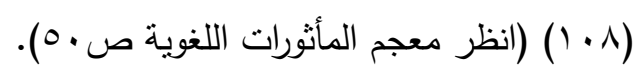

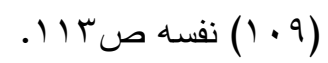

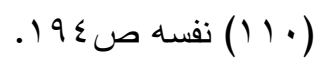
. (ط) (1) (1)

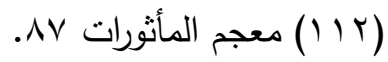

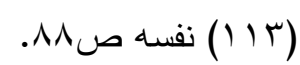
.111 نفسه (1) (1) (1) (1) .

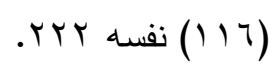

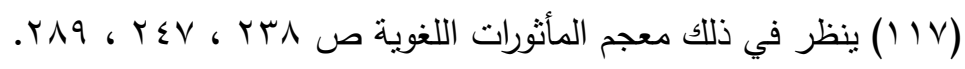

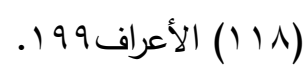

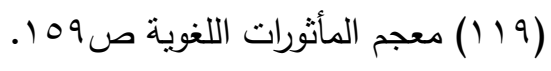

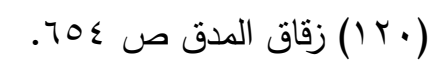

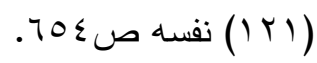

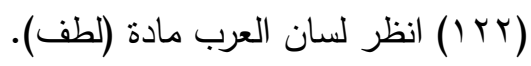

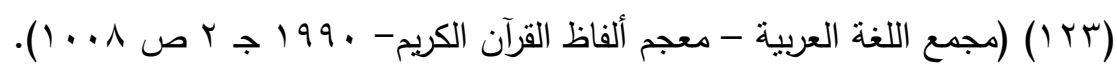

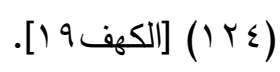

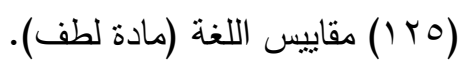

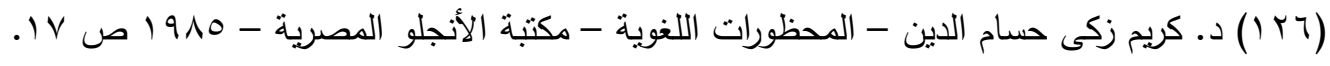

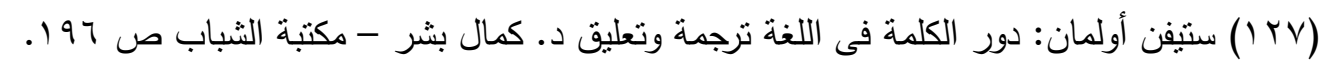

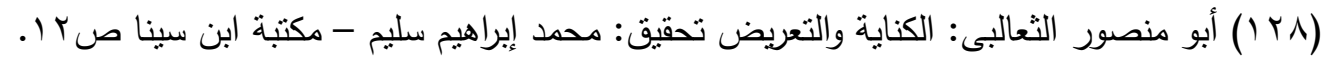

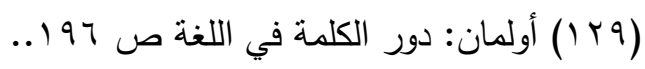

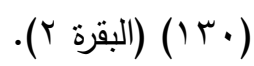

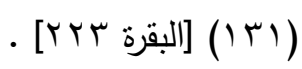
VO

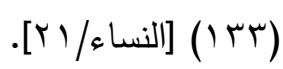

(ـ ب ا) انظر المنتخب من كنايات الأدباء وإشارات البلغاء- للجرجانى - تحقيق د. محمد شمس الحق شمس - ط مجلس دائرة

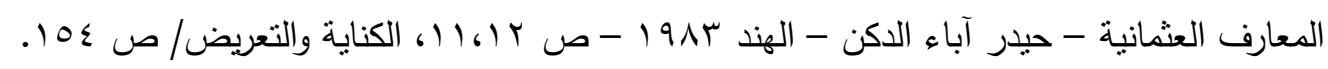

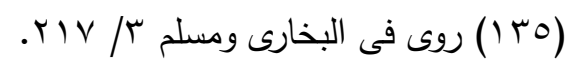

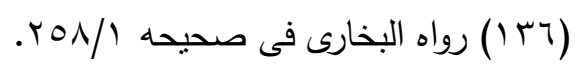

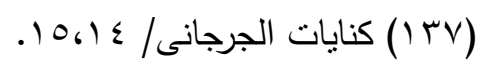

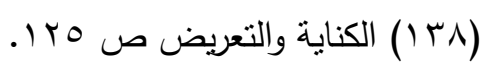




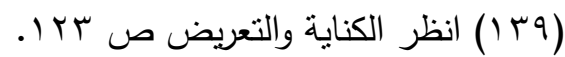

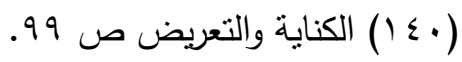

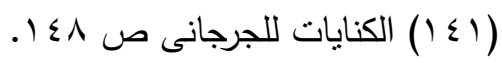

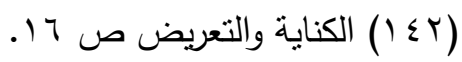

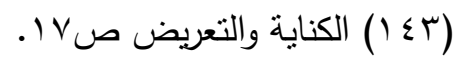

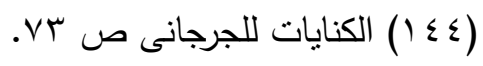

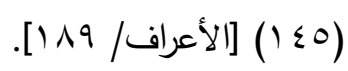

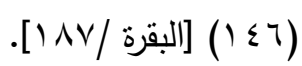

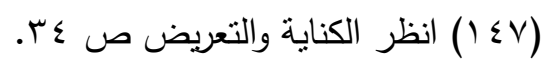

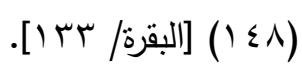

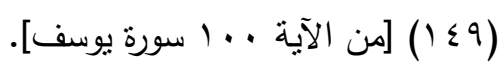

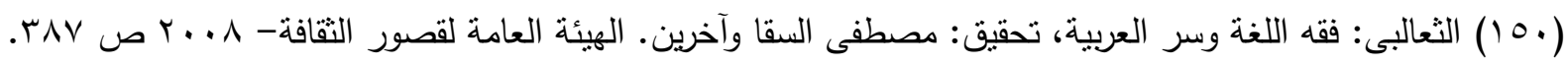

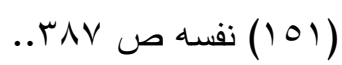

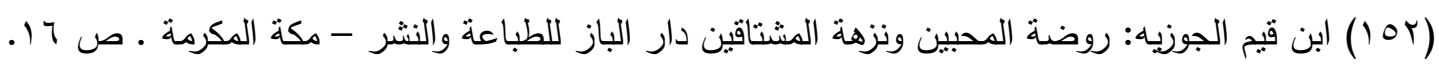

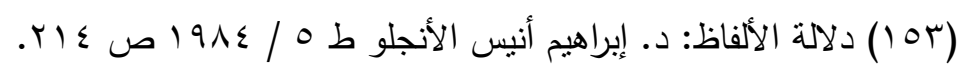

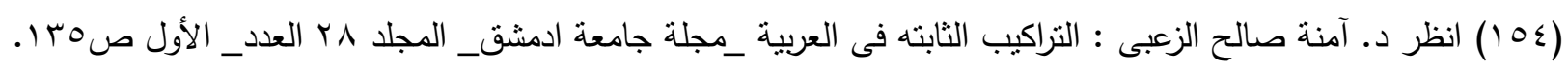

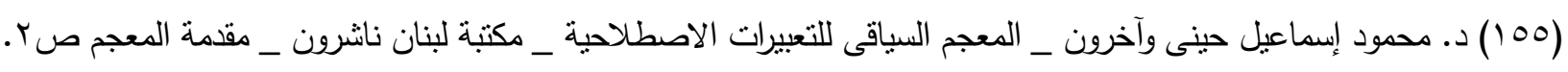

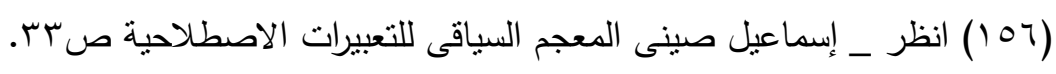

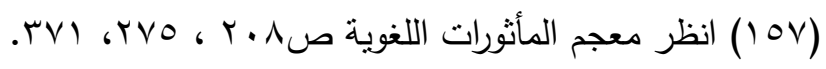
(101) -ابن حزم الأندلسي - طوق الحمامة في الألفة والألاف - تحقيق د.الطاهر أحمد مكي - دار المعارف ص 9 - 9 ـ

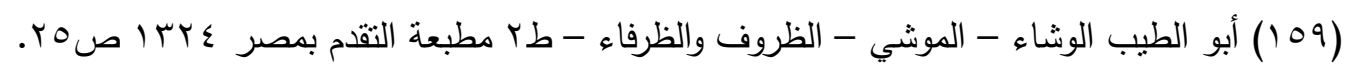

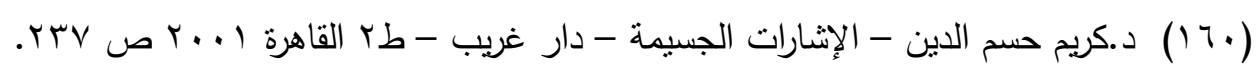

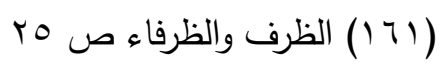

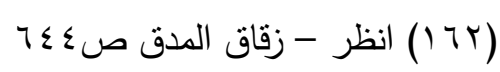

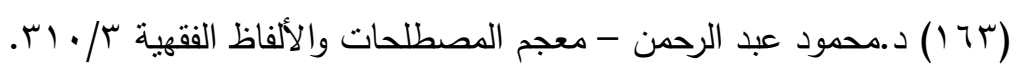

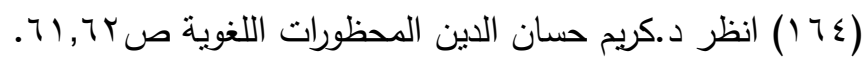

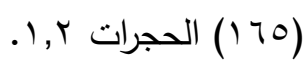

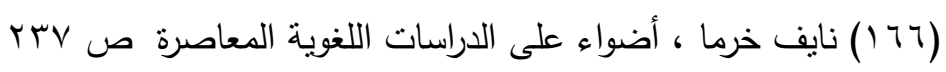

